Article

\title{
Bringing Back the (Ancient) Bodies: The Potters' Sensory Experiences and the Firing of Red, Black and Purple Greek Vases
}

\author{
Sanchita Balachandran 1,2 \\ 1 The Johns Hopkins Archaeological Museum, Baltimore, MD 21218, USA; sanchita@jhu.edu \\ 2 Department of Near Eastern Studies, Johns Hopkins University, Baltimore, MD 21218, USA
}

Received: 27 March 2019; Accepted: 27 May 2019; Published: 4 June 2019

\begin{abstract}
The study of Athenian black-figure and red-figure ceramics is haunted by nearly a thousand "hands" of the artisans thought to be responsible for their painted images. But what of the bodies attached to those hands? Who were they? Given the limited archaeological and epigraphic evidence for these ancient makers, this study attempts to recover their physical bodies through the ceramics production process — specifically the firing of vessels—as a communal activity potentially including a large cast of participants including craftsmen and craftswomen, metics, freed people and slaves. Using an experimental archaeology approach, I argue that we can begin to approach the sensory experiences of ancient potters and painters as they produced all the colored surfaces (and not only images) that endure on Greek vases. I propose a four-stage sensory firing in combination with the three-stage chemical firing process known for the production of Athenian ceramics, suggesting that each stage - and the colors produced at each stage—-had their own "sensory signatures." Examining extant vases with this awareness of the bodily experience of their ancient makers has the potential to bring back these ancient bodies, moving us beyond the limiting narrative of a single hand wielding a paint brush.
\end{abstract}

Keywords: Greek ceramics; Athens; ceramics production; red-figure; black-figure; sensory experience; potters

\section{Introduction}

Disembodied hands haunt the study of the ancient black-figure and red-figure Greek ceramics made in ancient Athens between 625 and 325 BCE. Of the extant figure-decorated vessels from this time period, nearly a thousand "hands" of the artisans responsible for their images have been identified by scholars of Greek vase painting, either through painted inscriptions or characteristic painting styles (Arrington 2017; Hurwit 2015; Williams 2017). But what of the bodies attached to those hands? The archaeological record is as yet fragmentary for these ancient craftspeople despite estimates that a significant percentage of the Athenian population may have been involved in the ceramics industry (Sapirstein 2013; Stissi 2012, 2016). The epigraphic record, both funerary inscriptions and "signatures" on pots themselves, tells us little about the lives of these workers. Furthermore, the ancient literary sources, so dismissive of the people who had to work with their bodies to earn a living, provide little detail about the experience of the low-status, often resident foreigner (metic) populations they derided (Dembin 2018; Hedreen 2016; Kamen 2013; Kasimis 2018; Kennedy 2014; Langdridge-Noti 2015). With the existing evidence so limited and freighted with censure, how can we begin to see the daily experience of the potters and painters from their own perspectives? The most enduring trace of the ancient potters' and painters' existence remains the ceramics they made and yet, our understanding of these surfaces has been limited to either the images or signatures painted or inscribed on them, 
which often assumes a single maker with a recognizable "hand." But what of the surfaces of Greek vases as a whole, the shades of red, black and purple that make the images and text legible and the whole bodies of the people who made them?

This paper argues that we have not fully considered the surfaces that the ancient Greeks potters and painters made as evidence of these makers' skill and embodied experience. Moving beyond the painted line as the marker of a single craftsman at work, I look to the firing of Greek ceramics as the key moment in the communal production process, one in which all of the work involved in throwing and painting an easily mutable clay object literally crystallized into its durable and indelible final form. The firing was responsible for the production of the range of colors-the reds, oranges, shades of black and brown and also the purples-for which Greek vase painting is renowned. ${ }^{1}$ These colors are iron compounds formed under specific temperature and environmental conditions and are chemically reproducible in an experimental archaeology approach. As will be described in this paper, such an approach to the firing of Athenian ceramics offers otherwise unknowable insights into the ancient production process. The firing is an intensely sensory experience, with specific senses heightened at different stages as different colors are being made on the vessels inside the kiln. The colored surfaces of vases therefore have not only a particular chemical, physical and artistic signature but also a "sensory signature." It is by considering these sensory cues that we may approach the bodies of ancient makers at work.

As the Hellenistic poem "Kiln" ${ }^{2}$ demonstrates, the firing was the stage most fraught with physical danger and the potential for financial loss from an unsuccessful firing. Heightening this sense of instability is the fact that vessels were stacked inside the kiln and could not be seen for the entirety of the long, multi-hour firing. Sight, of at least the ceramics themselves, was occluded, requiring those who tended the kiln to be all the more attentive to other sensory cues-sound, touch, smell and even taste- to ensure a favorable outcome. Recent scholarship has begun to articulate the "multimodal" ways in which the senses operated in antiquity by exploring how ancient peoples' sensory experience involved gaining information from multiple senses at the same time (Bradley 2015; Butler and Nooter 2018; Butler and Purves 2013; Day 2013; Hamilakis 2013; Purves 2018; Rudolph 2018; Squire 2016). While ancient philosophers assigned a hierarchy to the senses, with "sight and hearing ... given pride of place," (Rudolph 2018, p. 1) over touch, smell and taste, this paper specifically considers a multimodal approach to the production of Greek ceramics, arguing that the surfaces and the vessels to which these surfaces belong must be approached with an attunement to all of their sensory aspects. While the material and physiological means by which sensory experiences were created may be reconstructed to some extent, the cultural and psychological factors framing those experiences are difficult to conjure because they were both individual- and context-specific. Here, I suggest that the chemical reliability of iron-rich clays and their color-bound oxidation states provide some of the material experience of potters tending a kiln but also allows us to better "see" - or rather also, hear, touch, smell and taste- the world of the ancient makers as they worked. Such a perspective insists on what Mark Bradley has called an "object -centered experience" (Bradley 2013, p. 132) of color, one that acknowledges a multi-sensory, synesthetic experience and contextually-contingent use of color in antiquity. While much of the extant ancient literature considers the color-experience of the consumers of color, such as the patrons using these vessels at the symposium, this paper insists on the color-experience of the producers of color. Doing so synaesthetically means imagining the potters' world beyond an interest in only these peoples' hands. Imagining these workers deploying all their senses also allows us to approach the colored surfaces of ancient Greek ceramics as having been produced through intentional interventions by the full bodies of their makers. Following Bradley:

1 This paper does not address "added colors" or other materials applied post-firing. For these techniques, see Cohen (2006) and Lapatin (2008).

2 See the translation by Marjorie J. Milne, published in (Noble [1965] 1988, pp. 190-91). 
Because of its close ties to objects in the environment rather simply to a part of the spectrum, the ancient color experience could tap into smell, touch, taste and even sound. For Greeks and Romans, color was a basic unit of perception, a source of information and knowledge and a tool for accurately understanding the world around them ... Using a single sense for all this was not always enough. (Bradley 2013, pp. 139-40)

Considering the making of color on ceramics as tied to an environment also raises an awareness of the firing of ceramics as both a communal and highly visible activity. Archaeological evidence from Athens and other sites in Greece suggests the clustering of ceramics workshops alongside major roads into and out of the populated center, both for ease of access by workers and patrons, as well as for safety reasons and concerns about pollution (Langdridge-Noti 2015; Sanidas 2013; Stissi 2012, 2016). The necessary external location of kilns also made the work of firing highly visible to passersby and other artisans involved in the ceramics industry. Firing itself likely required at least two, if not more bodies at work collaboratively and the relatively long duration of the firing-anywhere from six to ten hours-would have also made this communal work necessary and noticeable. ${ }^{3}$ To a more careful observer, the varied cadence of firing would also have been recognizable, as the production of different colors through different phases of the firing required different body movements and produced variations in flame and smoke that would have been seen and inhaled by those at work as well as by those passing them. Considering the firing from this expanded spatial and social perspective already forces us to take seriously the fact that these colorful ceramics were produced through specific interactions between their makers and their environment, both within and around the kiln, as well as beyond their workspaces. Even from a roadside perspective, it must have been clear that the kiln attendants relied on their bodies and their associated senses, something that was open to elite censure:

... the illiberal arts (banausikai), as they are called, are spoken against and are, naturally enough, held in utter disdain in our states. For they spoil the bodies of the workmen and the foremen, forcing them to sit still and live indoors and in some cases spend the day at the fire. The softening of the body involves serious weakening of the mind. (Xenophon, Oikonomikos $4.2-3)^{4}$

Ancient elite anxieties about the baseness of the senses, the corresponding baseness of those who relied on them and their proximity to animals who, by their nature were more attuned to such cues, likely contributed to the lack of (ancient) interest in the bodies of the banausoi (the artisan class). ${ }^{5}$ But this disdain and disinterest has had lasting implications for the scholarship on Greek vases, ignoring the intellectual and experiential knowledge of these ancient makers and reducing their bodily labor to only their hands.

This paper seeks to "bring back the ancient bodies," but whose bodies? In addition to being disparaged as banausoi, a significant percentage of this population was identified as resident foreigners (metics) (Kamen 2013; Kasimis 2018; Kennedy 2014). As it was illegal for metics to earn a living through landowning as was the Athenian ideal, images of them at work, often in craft activities, circulate perhaps as a kind of advertisement between 540 and 460 BCE (Chatzedemetriou 2005; Lewis 2010). The number of men depicted in various stages of ceramics production or named in inscriptions, has led to an assumption of primarily male craftsmanship and apprenticeship, even though at least three

3 While it would be physically possible to carry out a firing alone, it seems unlikely in an industry that had access to cheap labor, especially slave labor.

4 Cited in (Hedreen 2016, p. 4).

5 See Dembin (2018) and Hedreen (2016) for a summary of statements disparaging artisans. 
women are depicted in tasks such as kneading $\mathrm{clay}^{6}$, possibly drawing ${ }^{7}$ and painting. ${ }^{8}$ Images have also been used to propose a hierarchy among the potters' and painters' workgroups ${ }^{9}$, though these assumptions cannot be verified through other evidence. We know nothing of the organization of staff or whether there was a need for there to be someone in charge of such a collaborative activity, though Dyfri Williams has suggested that, in the absence of the name for "kiln master," an individual such as the bald man with a stick at a kiln in the Leagros Group hydria in Munich was responsible for oversight of the work. ${ }^{10}$ We also do not know how (or if) labor was divided among potters and painters and questions as to whether pots would have typically been fired by the potters who threw them or if firing was a specialized skill practiced by a only few key artisans in the Kerameikos remain unanswered. Additionally, while the few images of firing ceramics show only male bodies at work, the limited evidence and complete lack of corroborating skeletal evidence neither confirms nor denies the extent to which this was the case. Women potters and painters would have been as physically capable as their male counterparts in physically tending and supervising the firing of a kiln; the fact that we do not see them doing so perhaps says more about the fragmentary nature of the extant evidence than reality. The bodies at stake in this paper, therefore, must include not only male "masters" and their apprentices but also skilled craftswomen who fell into the metic tax category of autê autês kuria ("her own master"), who might well have subcontracted out their labor to other artisans or even overseen their own workgroups (Kennedy 2014). In addition to these bodies, we must also include the bodies of apprentices, ${ }^{11}$ most of whom would have begun their tutelage as children and may have been boys as well as girls, as well as the bodies of freed people and slaves. ${ }^{12}$ Imagining a firing as potentially including this larger cast of participants in motion, all focused on the collaborative work of successfully producing colorful ceramics, moves us beyond the limiting narrative of a single hand wielding a paint brush.

\section{Chemically Bound Color: The Three-Phase Firing}

Despite early interest in the techniques by which ancient Greek ceramics and particularly their "black gloss" was made, this technological and increasingly specialized scientific literature has rarely been fully integrated into the art historical understanding of Greek vases. ${ }^{13}$ To quote W.D. Kingery whose landmark work first chemically characterized the surfaces of Greek ceramics, "the view that there was a single unchanging method of preparing Attic glosses and colors for painting pottery is much too simple" (Kingery 1991, p. 52). But recent findings ${ }^{14}$ demonstrating the flexibility and variability of ceramics production practices have had a limited impact on the vase literature, in part because the important work of Joseph Veach Noble continues to be the most accessible way to understand and teach ancient Greek ceramics production (Noble [1965] 1988). Noble's enduring work describes painting images on clay pots with slip (a thinned clay), adding inscriptions in a thinned slip or slip mixed with iron-based pigments, followed by a single three-part firing process (Figure 1) that includes an oxygen rich first phase, a second oxygen-poor reduction phase and a final re-oxidation phase, all at

6 See Penteskouphia Pinax, Berlin Antikensammlung, inv. F891.

7 See Athenian red-figure kalpis hydria in Vicenza, Banca Intesa inv. 2, attributed to the Leningrad Painter, dated to c. 470-450 BCE. I would argue that this figure may be drawing rather than painting based on extant evidence for drawing still visible on ceramics. See Balachandran (2018).

8 See black-figure Boeotian skyphos, Athens, National Museum, inv. No. 442., dated to 400-390 BCE.

9 Heilmeyer (2004) suggests that the term "workgroup" is more accurate for groups of people working together, while "workshop" suggests a physical location for their work.

10 Williams (2016). See the Leagros Group hydria, Munich Antikensammlung, inv. 1717.

11 See Hasaki (2012). Venit (1988) mentions three daughters who apprenticed with their painter fathers.

12 Williams (2009) mentions the late 6th century painter Lydos who signs a vase, "Lydos painted [me], being a slave."

13 Saunders et al. (forthcoming) and Maniatis et al. (1993) provide a useful summary of past attempts to characterize black gloss.

14 Aloupi-Siotis (2008), Chaviara and Aloupi-Siotis (2016), Cianchetta et al. (2015a, 2015b), Gliozzo et al. (2004); Kingery (1991); Lühl et al. (2014); Maniatis et al. (1993); Schreiber (1999); Walton et al. (2013a, 2013b, 2015). It should be noted that there are some debates among these scholars regarding the chemical characterization and production technologies of ancient Greek ceramics. 
different temperatures. While this process is still essentially true, it needs significant expansion if we are to recognize the virtuosity of the kiln workers' expertise. Importantly, the replication experiments reported by Noble and conducted by potter and curator Fong Chow of the Metropolitan Museum of Art, were completed using an electric kiln, a piece of modern equipment which produces entirely different sensory cues than ceramics fired in a wood-fired kiln. An electric kiln also does not have the same degree of unreliability inherent to a wood fired kiln and I would argue that the ancient potters' ability to manage and respond to the unpredictability of the kiln and the environment was essential to their sensory experience of the firing. The work presented here therefore offers a markedly different perspective on ceramics production to the method Noble put forward; even if the chemical changes in the iron-rich clay are the same in both an electric and wood-fired kiln, the kiln attendants' experience of producing the different colors is not.

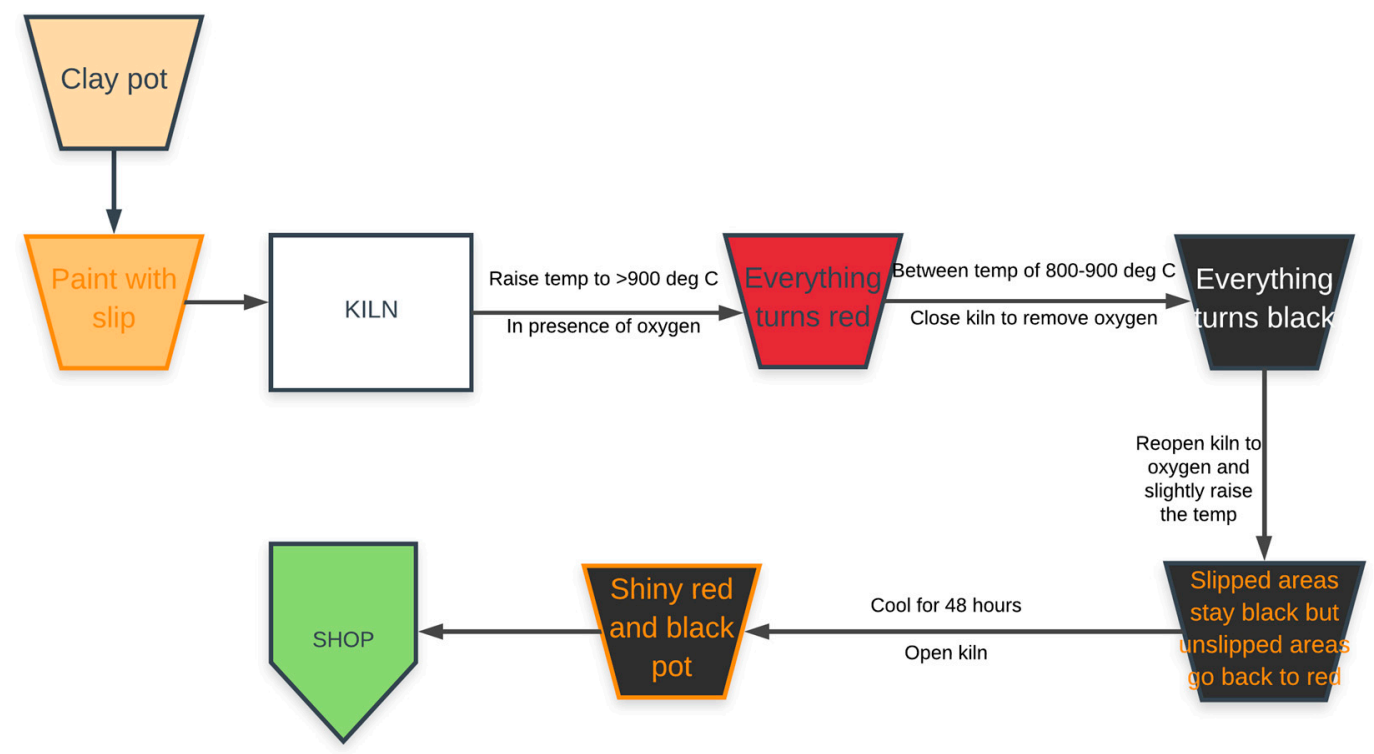

Figure 1. The single three-phase firing as described by J. V. (Noble [1965] 1988).

The exploration of the sensory signatures of the colored surfaces of Greek ceramics grows out of eleven subsequent test firings of approximately 200 replica red-figure vases and tiles in a custom-built updraft wood-fired kiln ${ }^{15}$ sited at Baltimore Clayworks (Figure 2). ${ }^{16}$ We did not intend to precisely replicate the experience of ancient Athenian craftspeople, particularly as we did not have access to their clay, as the Athenian clay source is as yet unknown. ${ }^{17}$ For our experiments, we selected a commercially available, iron-rich, illitic clay with a low calcium content ${ }^{18}$, all characteristics identified in Athenian ceramics. Despite not having the "original" clay, the repeated preparation and firing of pots in the same

15 See Hyleck et al. (2016). A description of the beehive shaped updraft kiln built for this project is available here: http:// archaeologicalmuseum.jhu.edu/the-collection/object-stories/recreating-ancient-greek-ceramics/week-9-building-and-breaking/.

16 The initial firing was the focus of the 2015 course "Recreating Ancient Greek Ceramics" co-taught by the author and potter Matthew Hyleck at Johns Hopkins University. A full account of the project is available at the website: http: //archaeologicalmuseum.jhu.edu/the-collection/object-stories/recreating-ancient-greek-ceramics/. The short film, Mysteries of the Kylix (https://vimeo.com/140393971) also documents this course and the first firing.

17 It is still unclear whether there was one preferred ancient Athenian clay source, though the specific preferred morphological and chemical characteristics of the clay used to make Athenian vases has been extensively studied by Aloupi-Siotis (2008), Chaviara and Aloupi-Siotis (2016), Cianchetta et al. (2015b), Lühl et al. (2014) and Walton et al. (2013b). The lack of a singular "identifiable" clay source suggests that potters may have mixed their clay to suit their personal preferences even if there were particular preferred clay deposits that were typically exploited. As all contemporary potters will attest, the choice of clay is the most fundamental and personal decision of any practitioner.

18 We used Cedar Heights Redart 103 earthenware clay from Pittsburgh, PA, as our base clay for both vessels and slip. Iron oxide pigments purchased from Kremer Pigments, NY, were utilized for painted inscriptions. 
kiln with the same workgroup of potters, painters and firing staff ${ }^{19}$ over the course of several months made certain sensory aspects of the production process noticeable and predictable. These sensory experiences were documented along with other aspects of the firing using photography, videography, handwritten firing logs and temperature measurements gathered from digital dataloggers placed at different shelf heights inside the kiln during firing. The regular pace of this work also made it possible to test both Noble's hypothesis for firing ceramics as well as recent materials science evidence that suggests more complex firing practices (Figure 3). ${ }^{20}$ Though the scholarship has disagreed on whether ceramics were fired only once or twice, both the scientific data and our own experimental work confirm that objects were and can be, fired more than once and that the results of these multiple firings are visually indistinguishably from those objects that are only fired once. While the frequency with which re-firings of the same object took place in antiquity is unknown, craftspeople were no doubt aware that slight imperfections resulting from a mis-firing could be corrected in a subsequent re-firing; this type of "multiple firing" would likely not leave any recognizable wasters and attests to the tremendous flexibility and virtuosity of the kiln attendants' practices. $^{21}$ The experimental process thus made it clear that while the chemistry involved in producing red, black and purple was not changeable, the processes by which one might induce the same chemical reactions were. In other words, there are many ways to fire a pot red, black and purple.

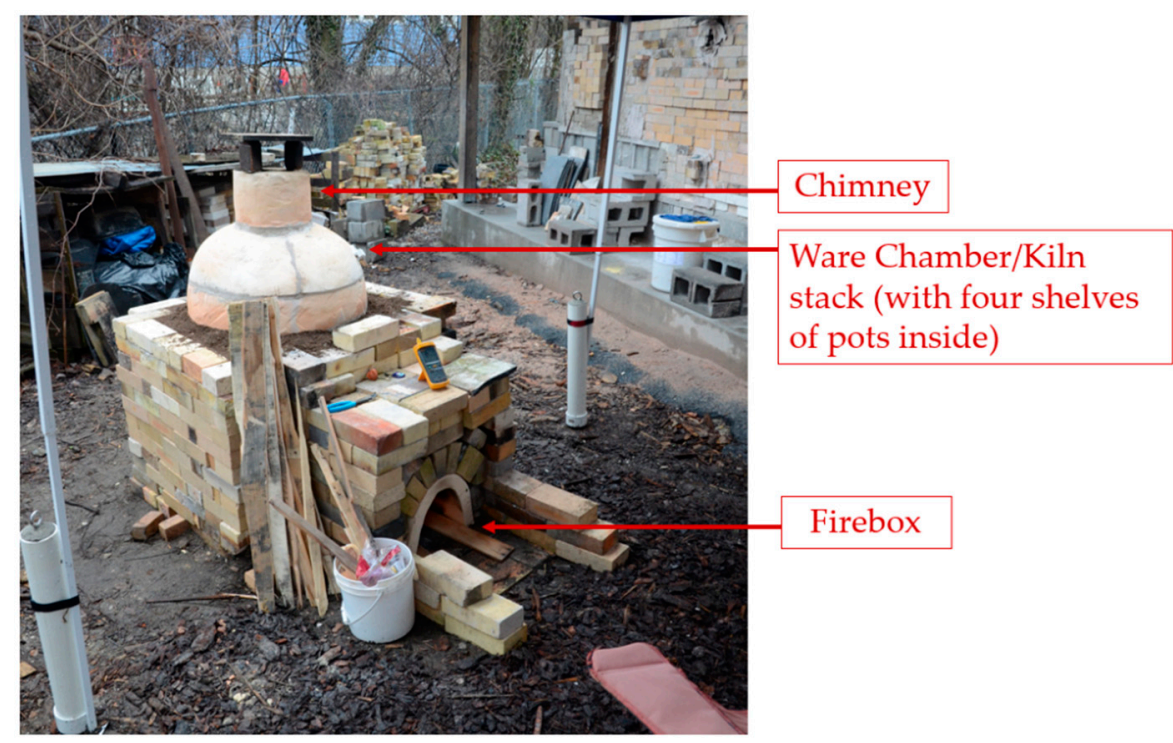

Figure 2. Kiln sited at Baltimore Clayworks. This design was based on a kiln built by Wissinger and Kahn and described in (Wissinger and Kahn 2008).

19 Nearly all vessels and tiles were made and assembled primarily by Matthew Hyleck with the assistance of potter Camila Ascher. Preparatory drawings on these surfaces were carried out by Karun Pandian, the author and Hyleck. The objects were slipped (i.e., painted) by the author and Hyleck. Firings typically involved at least four participants, with Hyleck as the kiln master, along with the author, potters Ascher and Anastassia Sovolieva, materials scientist Patricia McGuiggan and classicist Ross Brendle. An additional four plates prepared in the black figure technique were provided by Eleni Aloupi-Siotis (Thetis Authentics, Ltd, Athens, Greece) for test firing.

20 Recent analyses at the Getty provide evidence that both the Kleophrades Painter and the Berlin Painter used more complex, multiple firing techniques. See Cianchetta et al. (2015a, 2015b), Maish (2008), Saunders et al. (forthcoming) and Walton et al. (2013a, 2013b).

21 Thus far, there is little evidence of kiln wasters specific to multiple firings, suggesting that more complicated multiple firings may have been a specialized practice. However, the regular refiring of pots to correct firing mistakes is to be assumed and has been raised by Aloupi-Siotis (2008). Noble considered re-firing ancient pots to correct ancient flaws, though he admitted that "this does raise the ethical and moral question as to whether it is proper to correct an error made by an ancient potter in firing his kiln several thousand years ago" (Noble [1965] 1988, p. 181). 


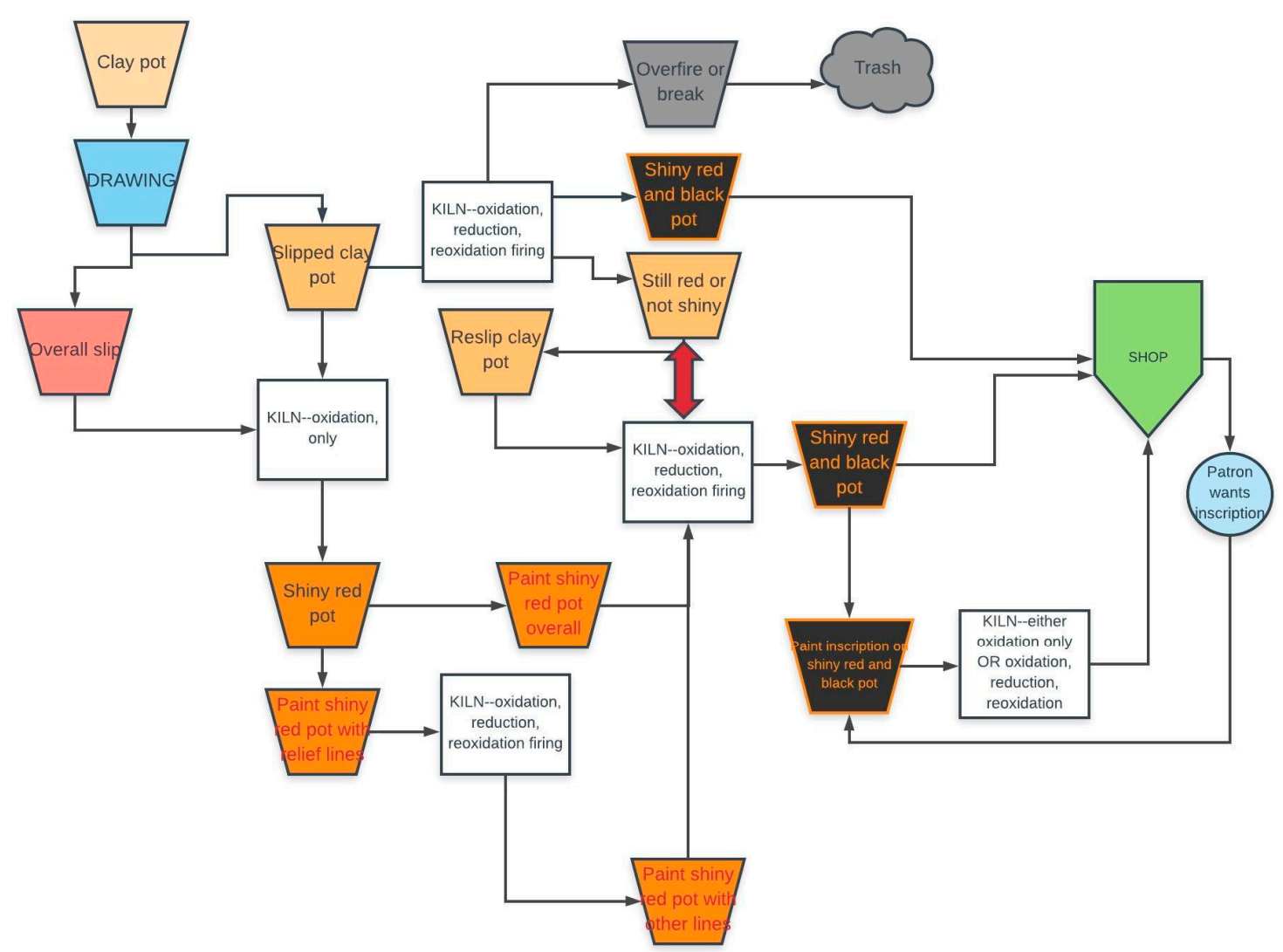

Figure 3. Multiple pathways for producing red and black ceramics, as tested experimentally.

Though the contemporary scholarship artistically, linguistically and temporally distinguishes between "black"-figure and "red"-figure vases, the origin of this terminology is likely more modern than ancient. ${ }^{22}$ In fact, only in the painting stage of ceramics production is there any change to the overall manufacturing process between these two "types" of objects: the firing remains exactly the same. Additionally, our current description of the surfaces produced through this process as "red" or "black" also ignores the range of reds, oranges, browns, blacks and purples that decorate these surfaces, all of which are a direct result of variations in the chemical composition of iron compounds present. For example, the color that might be described as "red" is likely either maghemite ( $\mathrm{gamma}-\mathrm{Fe}^{3+}{ }_{2} \mathrm{O}_{3}$ ) or hematite (alpha- $\mathrm{Fe}^{3+}{ }_{2} \mathrm{O}_{3}$ ), while the "black" is related to darker iron compounds such as magnetite $\left(\mathrm{Fe}^{2+} \mathrm{Fe}^{3+}{ }_{2} \mathrm{O}_{4}\right)$, hercynite $\left(\mathrm{Fe}^{2+} \mathrm{Al}_{2} \mathrm{O}_{4}\right)$ or wustite $(\mathrm{FeO})$, with other colors formed from mixtures of these compounds. ${ }^{23}$ Furthermore, all of these compounds are formed under intentionally induced, distinct environmental and temperature conditions with specific sensory cues associated with them.

Ancient potters utilized multiple strategies to manage the risk of the firing process. John Papadopoulos has documented numerous ancient Athenian "test pieces" that were drawn out through spy-holes in kilns to identify what colors were being produced inside them during the firing. ${ }^{24}$

22 I am grateful to H. Alan Shapiro, David Saunders, Annette Giesecke, Jennifer Stager and Andrew Stewart (through Jennifer Stager) for their thoughts on whether the ancient Greeks themselves described or distinguished their own ceramics in this way. Shapiro suggested that these descriptive "categories" of objects perhaps developed in the 19th century scholarship and not in the ancient world.

23 See Cianchetta et al. (2015b), Gliozzo et al. (2004), Lühl et al. (2014) and Maniatis et al. (1993). Note that there are some disagreements in the scientific literature about the characterization of specific iron oxides, though there is consensus that black iron oxides are only formed during the reduction phase.

24 See Papadopoulos (2003). Some of the painted plaques from Penteskouphia show kilns with delineated spy-holes (small upside-down " $\mathrm{u}$ " shapes) which could have been opened to draw out test pieces. It is unclear from the extant archaeological evidence how typical this feature was. See Hasaki (2002) for kiln evidence. Our kiln did not include a spy-hole. 
Spy-holes may also have been used to look inside the kiln to see if materials with specific melting temperatures had become molten. ${ }^{25}$ Even with test pieces or highly sensitive temperature gauges (as in our case), contemporary potters continue to rely on sensory evidence such as the "complexion of the flame" 26 shooting out of the kiln chimney or distinctive changes in smell to either mark or introduce transitions between different phases of the firing. This combination of visual and sensory attunement is essential to gauging the progress of the firing process and to correct potential mistakes before they resulted in the loss of an entire kiln load. ${ }^{27} \mathrm{I}$ believe this was also true of ancient ceramics production. Ancient potters were likely not aware that they were producing "hercynite" black or "magnetite" black; rather, it was their senses that allowed them to be aware of when they were passing through what Ninina Cuomo di Caprio called "critical zones," that is, phases of the firing we now recognize as chemical-physical transformations with irreparable consequences (Cuomo di Caprio 1984, p. 77). For the ancient potters, these "critical zones" were likely only gauged in shades of red and black.

I will begin with a brief overview of the chemistry of a firing and the colors produced at different stages, based on published analyses of ancient Athenian ceramics. ${ }^{28}$ Figure 4 illustrates a single three-stage firing using temperature data points from a test firing conducted in November 2016. The four different graphed lines correspond to the temperatures reached at each of the four different shelves inside the kiln, with the blue line ("saggar A") referring to the lowest shelf just above the firebox while the orange line ("saggar D") refers to the shelf at the top of the kiln nearest to the chimney. The variations in the graphed lines remind us that individual shelves (even within the same kiln) experience different micro-environments; thus the location of pots, that is, their position relative to the heat of the flame and their proximity to other pots, has significant consequences for the colors produced on their surfaces.

As the firing begins, all the pots inside the kiln are red, including images and inscriptions that have been painted using slip and the slip/pigment mixture, respectively. As the heat rises, the kiln is filled with oxygen and all of the surfaces (including the slipped and inscribed areas) of the vessels became brighter shades of red and orange in this "oxidation" phase. The iron compounds produced during the higher temperatures of this oxidation phase are primarily hematite. After reaching an optimal temperature ${ }^{29}$, an organic substance-thought to perhaps be wet wood or in our case, olive pits and damp hedge clippings-is introduced into the firebox and any ports that allow oxygen into the kiln are closed up. This immediately induces a smoky environment inside the kiln as the fire is choked from a lack of oxygen, beginning the "reduction" phase. On the graph, this short phase begins at 1000 degrees and falls quickly to a low of 800 degrees, as the temperature inside the kiln plummets due to a lack of oxygen. During this phase, all of the ceramic surfaces turn black due to the formation of black iron compounds. Importantly, a thin layer of glass forms over only the slipped areas of the ceramics (Aloupi-Siotis 2008; Cianchetta et al. 2015a, 2015b; Maniatis et al. 1993); this layer not only provides the sheen seen on these areas when the firing is completed but also plays an important role in the subsequent "re-oxidation" phase. In this final phase, the firebox and chimney are re-opened,

25 Contemporary potters use "cone packs" with refractory materials that melt at specific temperatures or cones to gauge the temperatures reached over the course of the firing. Tonks (1908) suggested that the ancient Greeks might have used gold and silver like cone packs.

26 Matthew Hyleck, personal communication, 10/26/2018. Noble also notes this awareness on the part of potters (Noble [1965] 1988, p. 154).

27 Contemporary potters assume that one third of a kiln-load is likely to be lost or damaged beyond sale, even in a successful firing.

28 For recent scientific and technical studies, see Aloupi-Siotis (2008), Chaviara and Aloupi-Siotis (2016), Cianchetta et al. (2015a), Cianchetta et al. (2015b), Gliozzo et al. (2004), Kingery (1991), Lühl et al. (2014), Maniatis et al. (1993), Schreiber (1999), and Walton et al. (2013a, 2013b, 2015). It should be noted that none of our experimentally produced ceramics were subjected to scientific analyses to verify the different iron oxidation states mentioned in the published literature; however, this is an area of future research.

29 The optimal temperature to be reached depends on the clay being used. For the RedArt clay used in our firings, it was necessary to reach 1000 degrees Celsius to ensure reduction. This optimal temperature may have been somewhat different for Attic or Corinthian clays. 
the reduction fuel is raked out, and new fuel is introduced as oxygen re-enters the kiln. Oxygen also diffuses into the unslipped surfaces of the pots, turning them from black to the iron reds maghemite and hematite. However, the slipped surfaces, that is, the black surfaces covered with a thin layer of glass, do not return to red as oxygen cannot diffuse through this vitreous layer. The painted inscriptions turn a combination of reddish-brown and purple as they were painted with a combination of slip and pigment. After a brief re-oxidation phase, the firebox of the kiln is closed up and the kiln allowed to cool over the course of approximately $48 \mathrm{~h} .{ }^{30}$ An image of the wares produced in the November 2016 firing is shown in Figure 5. Figure 6 shows a cup before and after firing, with the added inscription "oxidation reduction." It is therefore the mixtures of iron compounds on ceramics surfaces (and the presence of vitreous or non-vitreous surfaces created through painting and its firing) that produces the multi-colored effect we see on the finished objects.

\section{November 2016 Firing}

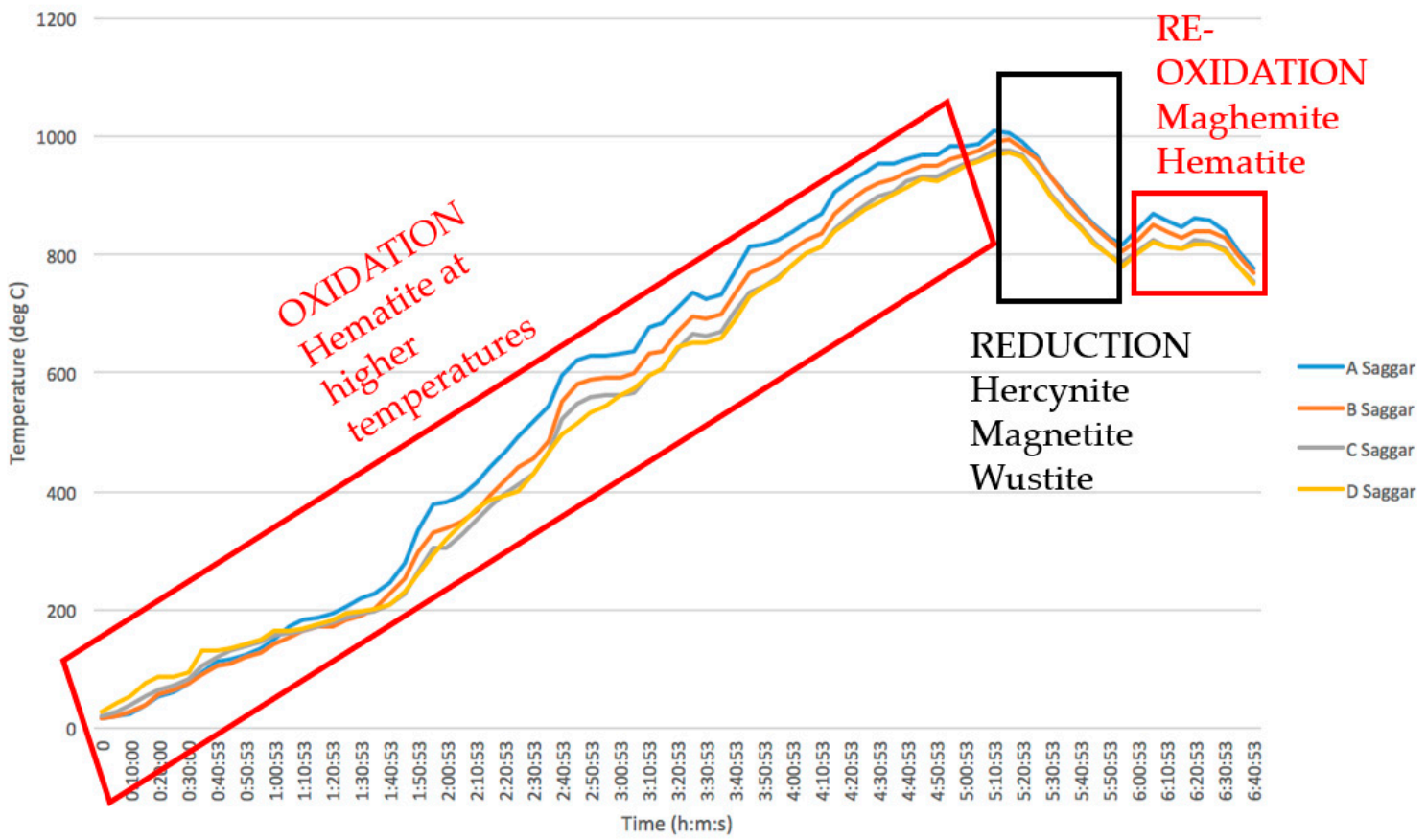

Figure 4. A graphic representation of the single three-phase firing sequence and some of the associated iron oxides as suggested in the scientific literature. This graph resulted from data gathered in a November 2016 test firing.

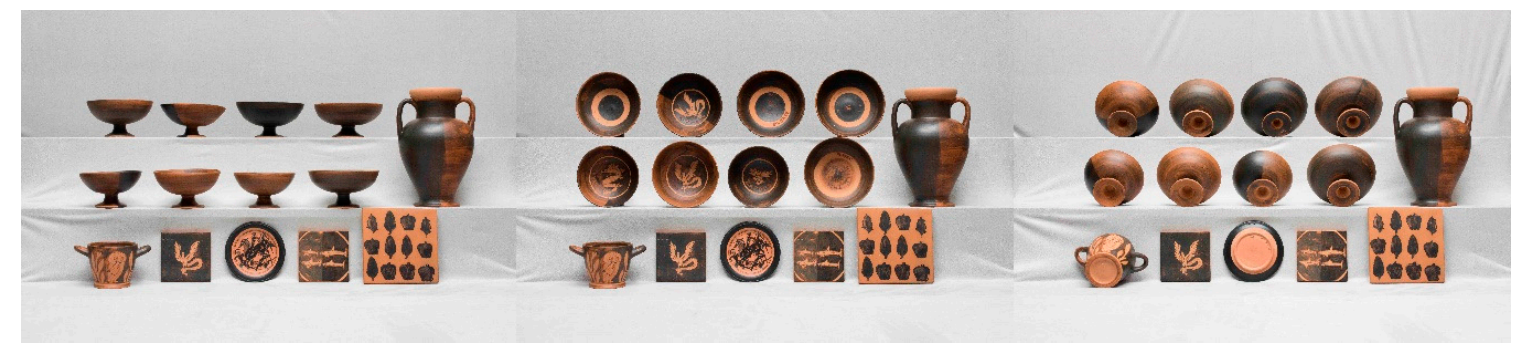

Figure 5. The fired wares produced in the November 2016 test firing. The black-figure plate was provided by Eleni Aloupi-Siotis of Thetis Authentics, Ltd., for test firing in our kiln.

30 Our datalogger information ends soon after the temperature fell below 800 degrees Celsius because the recording equipment was disconnected after this time. 

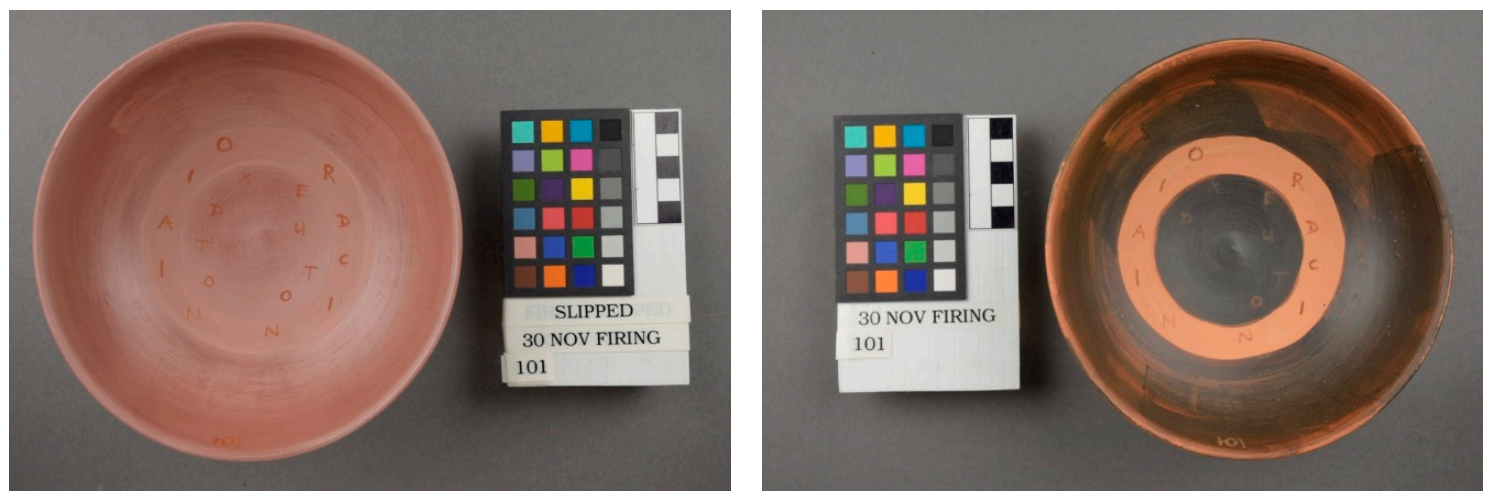

Figure 6. The same cup, before (left) and after (right) firing. The areas that turned black were slipped. The words "oxidation" and "reduction" were written in slip mixed with a yellow iron oxide pigment. This object was fired only once.

\section{Sensorially Guided Color: The Four-Phase Firing}

Thus far, I have described color as chemically-bound but the remainder of this paper will consider what ancient kiln attendants might have experienced sensorially as they progressed through the "critical zones" of the firing that produced the colors they desired. The success of a firing and indeed the viability of a ceramics shop depended on an acute awareness of these sensory cues. Many of these cues are fleeting, requiring all the more attunement to events such as a brief change in the fire's smell and its triggering of taste sensations, the appearance and disappearance of a whooshing flame or the sudden and short-lived sounds inside the kiln. Becoming aware of these moments forces a recognition of "the collective significance of the senses as modes of communication and information" (Bradley 2015, p. 9), something all the more critical when potentially saleable pots were obscured from view inside the kiln. While the sense of sight was crucial to the firing process, I wish to emphasize that the firing is a very sensory-intense experience requiring all of the senses to work in concert. Furthermore, I suggest that certain senses are heightened at particular stages of the firing and are therefore more directly associated with the production of certain colors. Based on experimental observations, I propose a sensory four-phase firing, in combination with a chemical three-phase firing (Figure 7). This four-phase firing includes: a warming/heating phase when touch and sound are essential and all vessels are a dull red; an oxidation phase when sound and sight are most relevant and the vessels are the bright red more associated with hematite; a reduction phase when smell and possibly taste are important for the production of the iron blacks and browns such as magnetite and hercynite; and a final re-oxidation phase when smell, taste and sound are associated with the production of a mixture of iron-oxidation compounds that are red, orange, brown, black and purple.

\subsection{Sensory Phase 1: The Touch and Sound of Dull Red Pots}

Potters, if you pay me for my song,

then I ask that you, Athena, hold your hand above the kiln.

-“Kiln," Life of Homer 14.1-14. ${ }^{31}$

It seems no coincidence that the poem "Kiln" begins with an invitation for Athena to come and hold her hand above the kiln. Not only does this suggest her blessing the potters' enterprise but also gives us valuable insight into the potters' environment at this first phase of the firing, the only phase when a hand - even that of a goddess - could be held safely above a kiln without being burned. This first part of the firing, beginning from ambient temperature and rising to above 500 degrees

31 I am grateful to Annette Giesecke for her translation. See West (2003, pp. 390-95), for the original Greek text. 
Celsius, involves the slow heating of the kiln and the wares stacked inside it such that any residual moisture is slowly evaporated off without risking the explosion of still damp pots in the kiln stack. The gradual warming of the kiln is also particularly critical for ensuring the physical integrity of the kiln and thus the success of the entire firing. Steam released inside the kiln walls at this stage is vented through otherwise unnoticeable gaps and fissures in the wall and these openings must be patched and stabilized during this phase's relatively low temperatures as the kiln will become too hot to touch in later stages. Touching the kiln is essential for assessing maintenance needs and this early part of the firing is characterized by a close physical interaction with the kiln: circling it, kneeling around it, pushing against its surfaces to check for points of weakness, reaching inside the firebox, and bending over the top of the chimney. (Figure 8). This phase also involves developing a kind of choreographed placement and stoking of fuel in the firebox, possibly olive wood branches in ancient Athens or in our case, chopped up pine boards from shipping pallets.

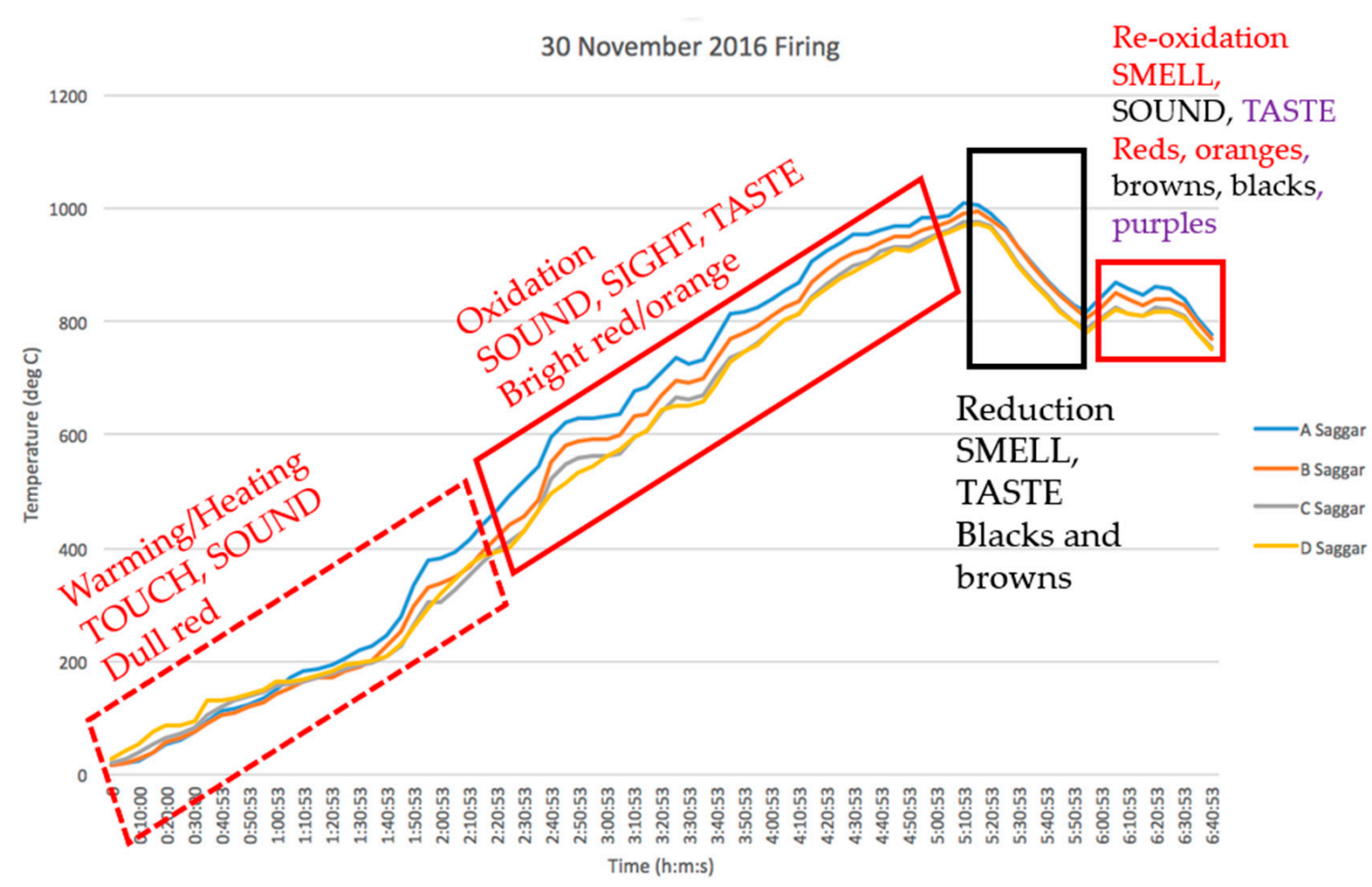

Figure 7. A graphic representation of the sensory four-phase firing sequence.
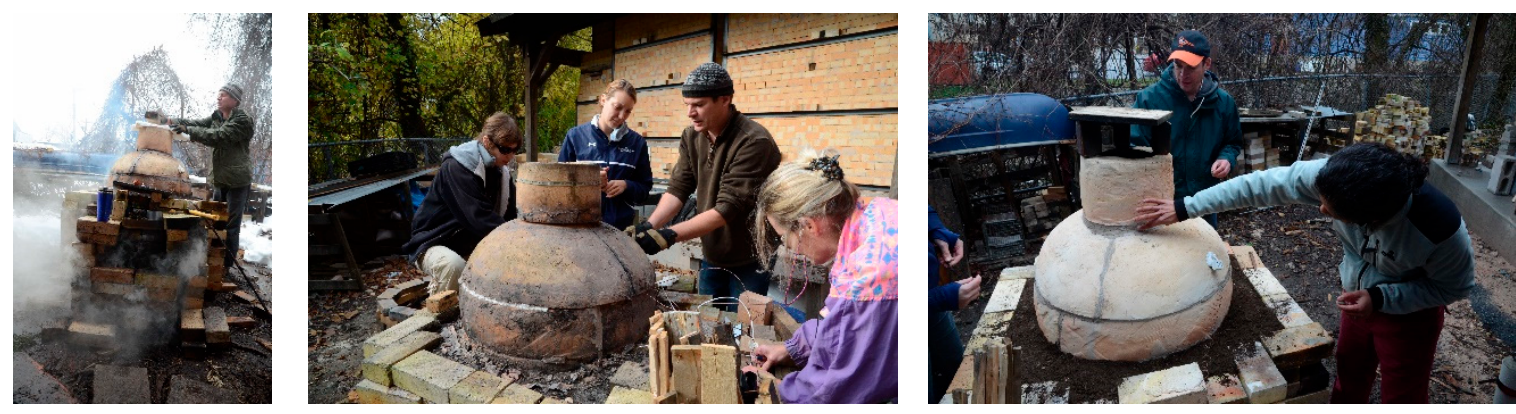

Figure 8. Touching the kiln in the warming/heating phase as it vents steam (left) and as fissures and cracks are patched (center and right).

The ability of touch, especially with one's hands, to probe and seek out the functional state of the kiln parallels the recognition by Greek philosophers that touch, though potentially misleading or untrustworthy, provided otherwise unknowable truth (Purves 2018, p. 2). Concerns over how and 
where touch took place, that is, its "unlocatability," made philosophers suspect this sense, classifying it "as a 'low' sense, best fit for the farmyard, bedroom or nursery, because it is the most proximal and immediate of the five and because ... it is common to all creatures" (Purves 2018, pp. 4-5). But for kiln attendants, touch was located at the surface of the kiln. Despite what Alex Purves calls the "downgrading of touch" in antiquity, it was a vital sense in this first phase of the firing, serving as a critical way to gauge the viability of the potters' most permanent and visible piece of equipment. Touch connected the bodies of attendants with their kiln, echoing Purves' observation that the skin functions as a "permeable border between ourselves and our world [in a way] that allows feeling to flow freely between the inside and the outside of the body" (Purves 2018, p. 3). This kind of physical intimacy, however, is short lived, as the kiln soon becomes dangerous to touch. For example, the entry from the February 2016 firing log states that when the kiln was touched at 876 degrees Celsius during the oxidation phase, "Matt burned his finger on kiln wall." The poem "Kiln" also alludes to the brief period in which touching the kiln is possible, as in its final lines, it warns that "whoever peeps over the top, may all his face be scorched" (West 2003, pp. 394-95). This early heating/warming phase is the only time when it would be feasible to even look over the kiln chimney, either with or without Athena's favor.

The second critical sense during this phase of the firing is hearing. Despite an ancient acknowledgement of the necessity of sound and its higher status relative to smell, taste and touch, concerns about where sound is located, its ephemeral and invisible nature, and how more attuned animals are to sound than humans made it an untrustworthy sense (Butler and Nooter 2018). But the ears are impossible to close off from sound, because "the ear draws inward. It soaks up information" (Butler and Nooter 2018, p. 2). Therefore, actually hearing specific sounds suggests selectivity on the part of the listener. Considering the cacophony of sounds that must have invaded the kiln attendants' ears in the Kerameikos, the ability to be acutely attuned to sounds inside the kiln was a cultivated and practiced skill. The early phase of the firing lasts between two to four hours and is characterized by the slow crackling of the fire as it slowly builds in the firebox with the regular and measured stoking of fuel under the chamber of stacked ceramics (Listen to Supplementary Multimedia File 1). Any auditory changes-typically fleeting-to this consistent rhythm can indicate potentially catastrophic damage to the kiln load. In the written log for the April 2015 firing, there were two short sounds at 11:29 and 11:31, at 430 degrees Celsius: "Bad sound in kiln, popping sound, MH [Hyleck] says it was probably a cone pack exploding." When the kiln was opened post-firing, it was clear that the sound had been related to two tiles exploding because they had not been fully dried before firing; the resulting fragments had ricocheted against other pots and into the bottom of the kiln (Figure 9). In the July 2016 firing, a delicate "pop" at the relatively low temperature of 157 degrees Celsius raised a concern about "exploding wadding," the small balls of refractory material that cushioned the different shelves of the stacking chamber. The significant consequences of this brief and delicate sound were not clear until the second sensory phase, described below. But at this first warming phase, the only hope was of pots reddening and remaining intact in the rising heat of the kiln. 


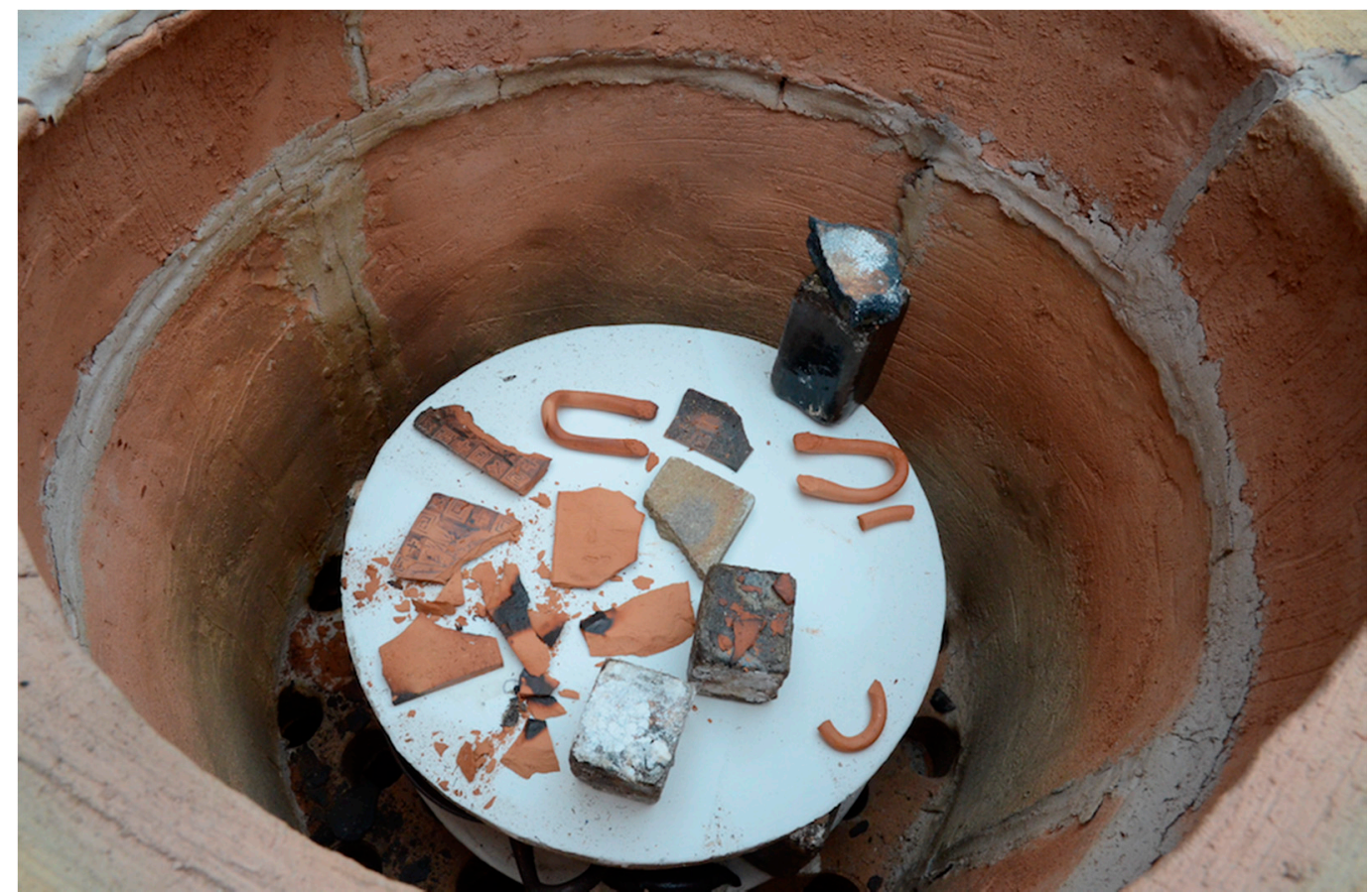

Figure 9. The explosion of test tiles in the April 2015 firing.

\subsection{The Second Sensory Phase: The Sound, Sight and Taste of Bright Red Pots}

The transition from the first to the second sensory phase of the firing is initiated by increasing the amount and speed with which additional fuel is introduced into the firebox. The decision to significantly raise the temperature of the kiln in anticipation of the next sensory phase (the reduction) is based on the lack of sensory cues such small sounds or steam emanating from inside the kiln. The jump in temperature is precipitated by a sudden acceleration in the rate of stoking the fire which gives the kiln a new "voice." The more gentle crackling sound of the fire in the first warming phase is replaced by a loud whooshing sound (Watch Supplementary Multimedia File 2), with the ferocity of this sound accompanied by the expulsion of bright orange embers and the startling appearance of a bright orange flame from the chimney for the first time in the entire firing (Figure 10). The suddenness and regularity (typically around 700 degrees Celsius) with which this flame erupted during this sensory phase suggests that it might have been a regular marker for the kiln attendants. In our firings, the words "BRIGHT ORANGE FLAME!!!" written in capital letters with exclamation marks appear in each of our eleven firing logs. That such a moment might be represented in a ceramics apprentice's dedicatory plaque (Figure 11) adds credence to the possibility that such an event was an important marker for ancient artisans. The auditory aspect of orange flame's sudden appearance recalls the way that sound was closely intertwined with voice and speech and how sound mediated the relationship between mortals and the divine. In describing Odysseus hearing Zeus' thunderclap as an omen, Butler and Nooter note:

in the hearing of voice, prayer, thunder and speech, an entire dialogue is played out among mortals and the divine. Each sound or speech is animated by the motion of an underlying significance to sounds, whether these sounds are ostensibly verbal or meterological. The sounds act as omens, bearers of meaning in a system of fate and prophesy that is as great and unknowable as the music of the spheres. Sound can mark our place in the world (as both space and time) but it does not always guarantee our agency. (Butler and Nooter 2018, p. 7) 

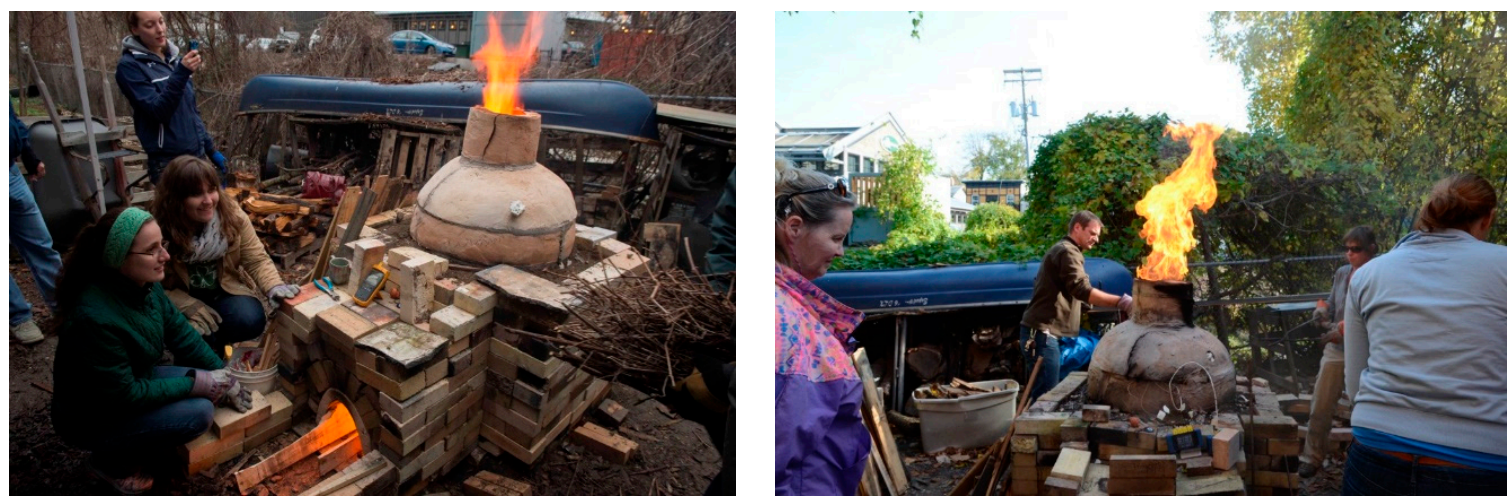

Figure 10. The eruption and persistence of a bright orange flame from the chimney in the oxidation phase.

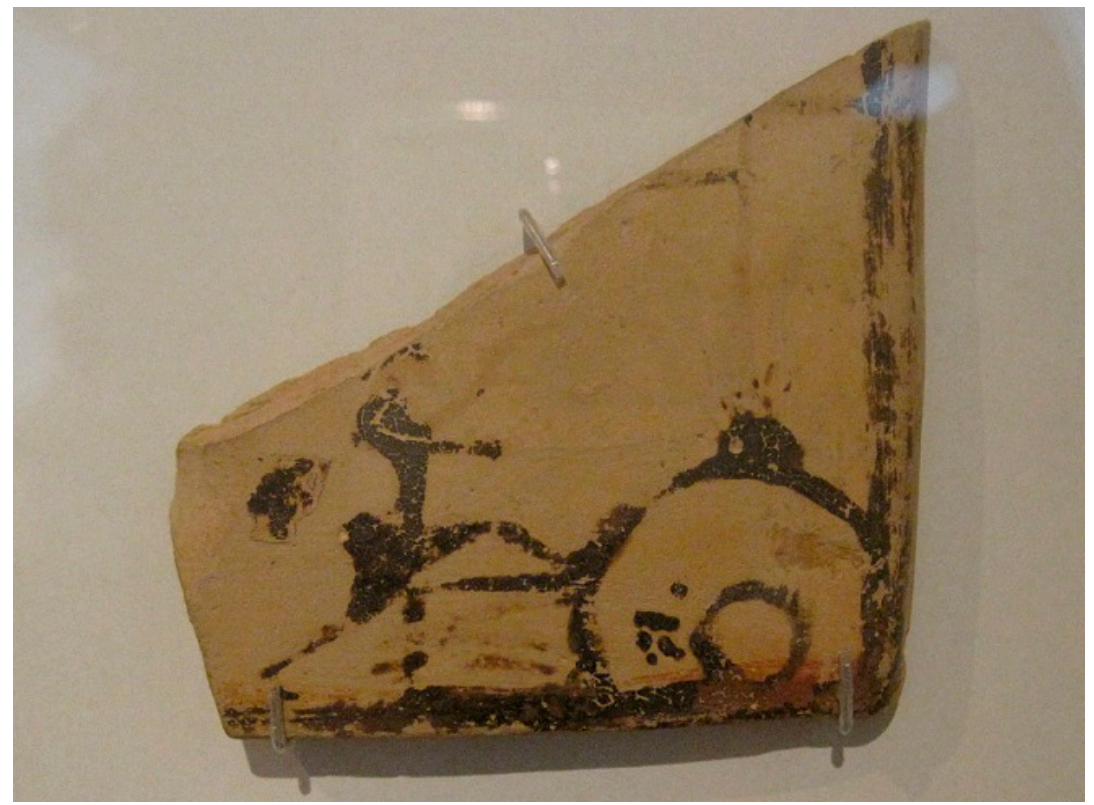

Figure 11. Pinax, Penteskouphia, Corinth, 575-550 BCE, Berlin, Staatliche Museen, F616. Author's own image.

The lack of agency on the part of the listener is underscored by the fact that this phase of the firing is fraught with danger, as an uncontrolled fire could not only destroy the kiln load but also the kiln, the environment and the people around it. The "kiln gremlins" described in the poem "Kiln" likely made their appearance during this phase (West 2003, pp. 392-93). The poem speaks of "Sytrips (Smasher) and Smaragos (Crasher) and Asbetos (Unquenchable) ${ }^{32}$ too and Sabaktes (Shake-to-Pieces) and Omodamos (Conqueror of the Unbaked)," all potential hazards at this phase. ${ }^{33}$ As mentioned in the previous section, in the July 2016 firing, a popping sound at 157 degrees Celsius had been the first indication that something had been dislodged from the kiln stack; a subsequent rumbling sound at 544 degrees Celsius was another cause for worry. On opening the kiln, it was clear that the rumble was related to the entire kiln stack leaning over during the firing after the wadding on a shelf had exploded, severely distorting our pots in some of the stack (Figure 12).

32 In his translation, West refers to Asbetos as "Overblaze," rather than "Unquenchable" as in Milne's translation in (Noble [1965] 1988) but both terms suggest a kiln grown too hot. See West (2003, p. 393).

33 Translation by Milne, as published in (Noble [1965] 1988, pp. 190-91). 


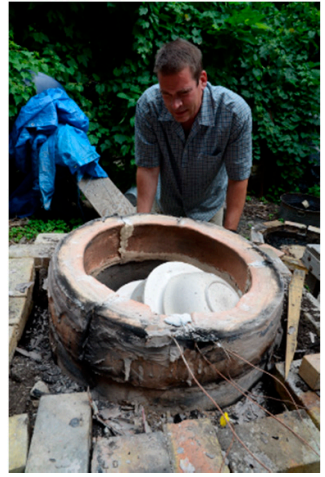

(a)

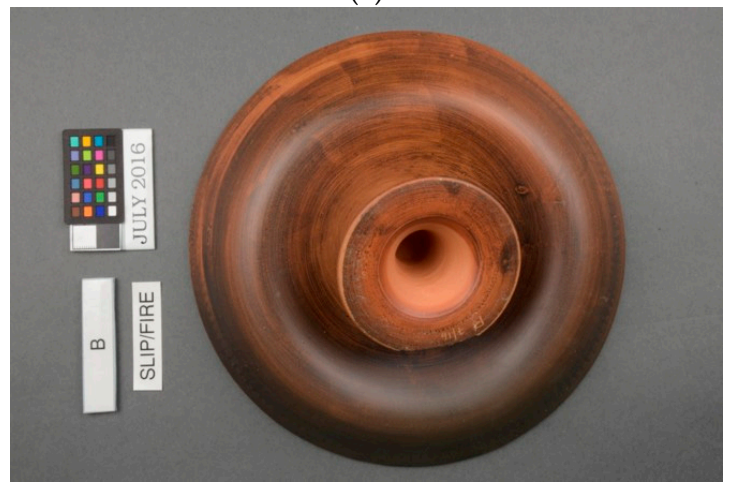

(c)

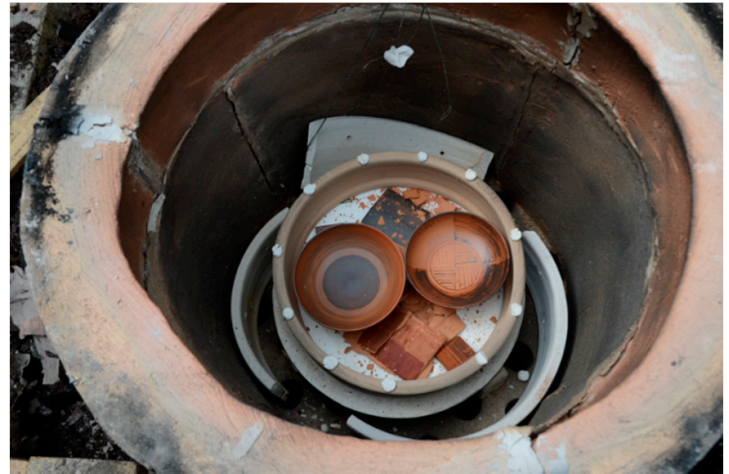

(b)

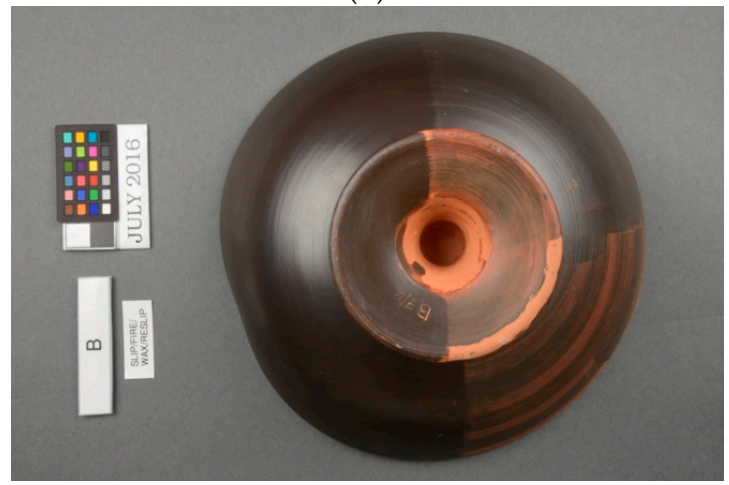

(d)

Figure 12. The leaned over kiln stack (a); the broken shelves inside the kiln (b); and the distorted pots (c,d).

Despite the anxiety inherent to this phase, it is also one of relative repose due to its long duration. We know nothing of when in the day firings took place or even if they were seasonal activities, but if people began working early in the morning, the long oxidation phase would offer an opportunity to break for a late-morning or midday meal taken kilnside. No doubt there were several opportunities to eat during the extended firing process and it is enticing to imagine what might have passed as a snack-olives and bread or some food specific to different metics' homelands? Were these foods shared and if so, did their taste bring another sensory association to the oxidation phase and the firing of bright red pots? Kelli Rudolph suggests that "to taste was to engage in a complex relationship with the flavors and substance of the foods consumed in a cultural and environmental context with all its pleasures and dangers" (Rudolph 2018, p. 6). Taste, then, is context-specific and communal as well as individual. Rudolph reminds us that "the act of eating has both selfish and yet unifying tendencies" (Rudolph 2018, p. 11) and that food consumed marked the status, identity and even geographical origin of both its maker and consumer (Boulay 2018; Hitch 2018). As most of our firings took place in cold and rainy Baltimore weather, our workgroup's shared sensory experience of this phase is associated with cups of soup laced with oyster crackers, greasy French fries and tumblers of hot chocolate. But taste is a complex and intimate sense, requiring a material to be placed inside the mouth and eventually becoming part of the taster's body (Rudolph 2018). For our own firings, our meals were linked to holding warmed (and warming) bowls of food, gulping hot beverages that traveled down our throats and feeling our stomachs fill in anticipation of the upcoming, stressful reduction phase. How then might we consider the bright orange-reds of Greek ceramics differently if we begin to imagine potters at their meals as these colors were being produced, snacking and perhaps warming the outsides and insides of their bodies as the pots themselves warmed to bright red? 


\subsection{The Third Sensory Phase: The Smell and Taste of Black Pots}

In "Kiln," the aim of the firing is that "the kotyloi and all the kanastra turn a good black ... be well fired and fetch the price asked." 34 The importance given to the "good" (deep? lustrous?) black on Greek pots has been a scholarly obsession since the eighteenth century, with much experimental and scientific work devoted to identifying how the "black gloss" was created (Saunders et al. forthcoming). Given the emphasis placed on this dark and shining surface, it might come as some surprise that the phase that produces this characteristic color is extremely short-lived, taking as little as $4 \%$ to $9 \%$ of the time of the entire firing. ${ }^{35}$ The dark iron compounds hercynite, magnetite and wustite can only be produced chemically between 1000 to 850 degrees Celsius and only in the absence of oxygen and this extremely tight temperature window demanded astonishing precision and coordination of the kiln staff. Once it was determined that the optimal temperature for beginning reduction had been reached ${ }^{36}$, all of the kiln workers would have been involved, either in introducing the organic material into the firebox or in sealing up the air vents leading into the kiln. Doing so in a synchronized manner would have been the most effective way to ensure that the atmosphere inside the entire kiln was as consistent as possible and that all of the pots were in turn becoming uniformly black.

The coordinated movement of the closing up the kiln has two immediate consequences. First, as the ports are closed, flames shoot out from both the chimney and the firebox, the only time in the firing that this occurs (Figure 13). Two ancient apprentice potters' plaques seem to show this precise moment (Figure 14) as flames lick the chimney and firebox edges, desperate for air. The other significant indicator of beginning reduction is the eruption of a sharp-smelling, gray, billowing smoke from these ports as the fire is choked. This dramatic moment (Watch Supplementary Multimedia File 3) assaults the nose, throat and eyes, causing people to cough and making eyes water. Here, then, is a clear example of how Greek philosophers conceived of how olfaction worked, that is, that the "smell-organ" was a "conduit between the inner body and the outside world," and that this "nose ... extended down into the throat and back into the ear-canal, the eyes and the brain" (Bradley 2015, p. 3). As with the other senses, the elite anxiety about the veracity of smell and its association with animals was not likely a concern of potters who were dependent on the powerful communicative aspect of this sense, particularly at this stage of the firing (Bradley 2015). In fact, noticing when the smell was suddenly less acrid cued attendants to re-induce the smoky, smoldering atmosphere, either by adding more reduction fuel or tightening up any vents in the kiln walls. This kind of attunement and adjustment is all the more impressive considering that there were other kinds of burning-of incense or flesh-occurring all around the workshops in the burial grounds of Kerameikos. Though a fleeting phase in the firing, it is also important to consider how the scent of reduction might have clung to the bodies of the workers long after the firing was completed. Did the smell of smoke linger on their hair and their clothes and thus announce their identities as potters as they walked home, visited the taverns or perhaps sold pots in the Agora?

34 Milne in (Noble [1965] 1988, p. 190).

35 This assumes that reduction takes between twenty to forty minutes over the course of an eight hour firing, which was our general experience.

36 As with oxidation, the optimal reduction temperature is clay dependent. For RedArt clay, beginning reduction around 1000 degrees centigrade was most effective. However, lower temperatures were workable for the test pieces sent to us by Thetis Authentics, Ltd. 

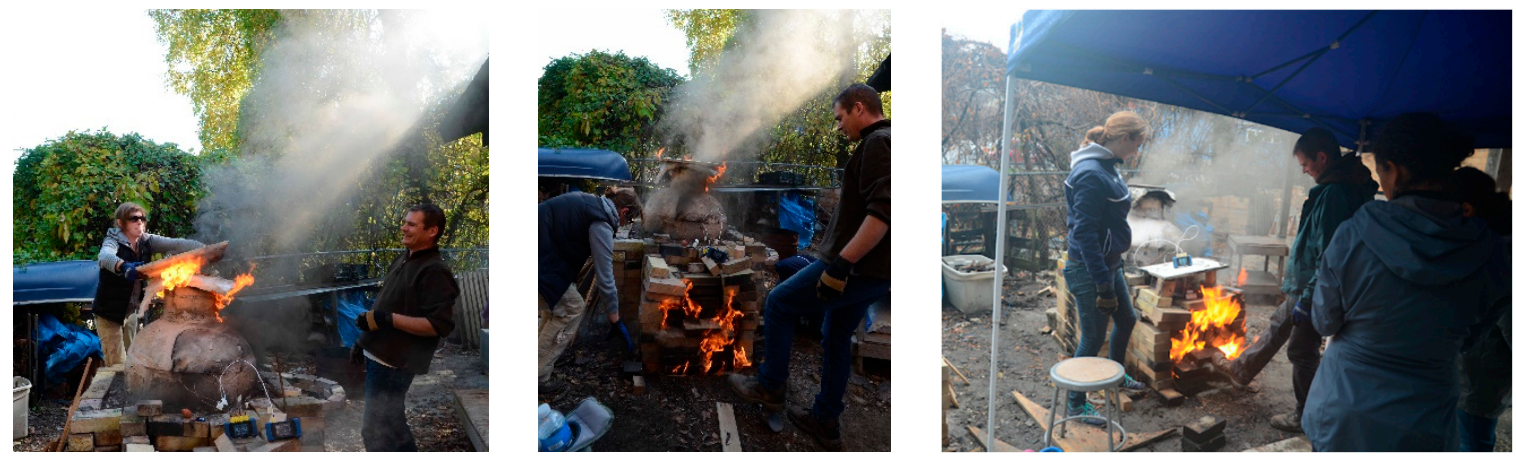

Figure 13. Closing the chimney and firebox to induce reduction results in fire erupting out of both these ports and the production of a gray smoke.
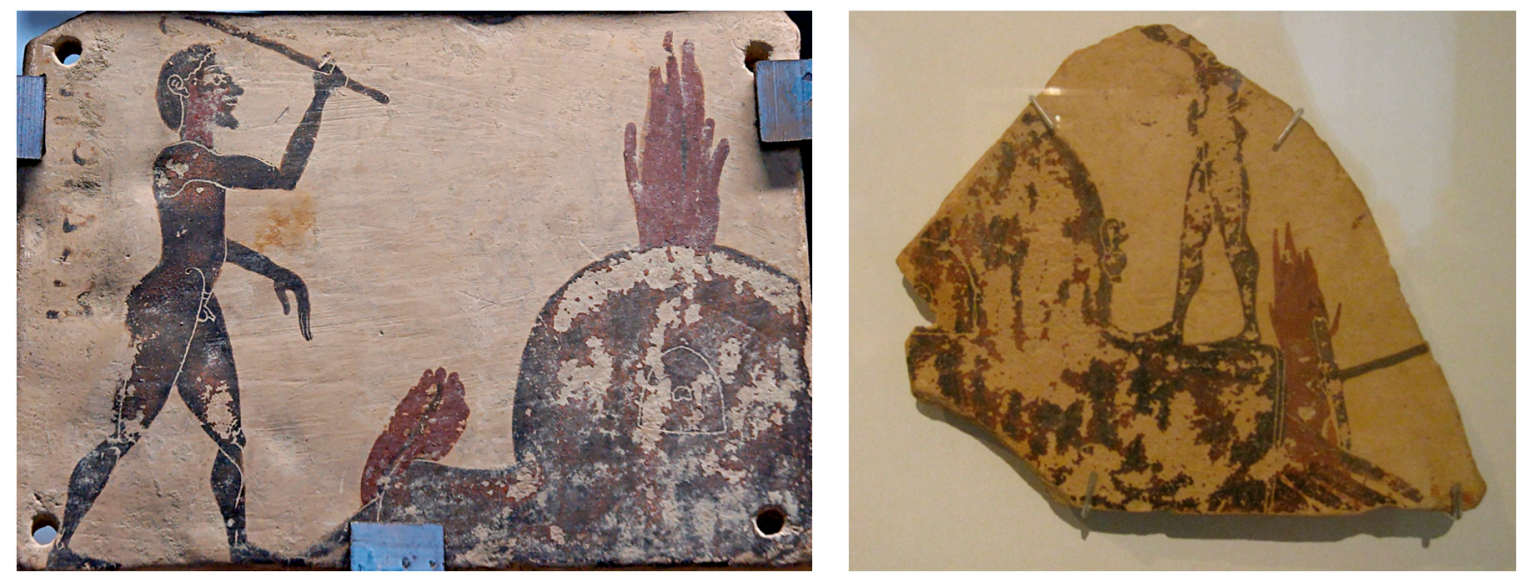

Figure 14. The beginning of reduction. Penteskouphia pinakes, Corinth, 575-550 BCE, (Left) MNB 2858, Louvre, Image from: https:/commons.wikimedia.org/wiki/File:Plaque_Penteskouphia_MNB2858.jpg; (Right) F827, Berlin Antikensammlung. Author's own image.

So how did ancient makers' bodies smell? My own children told me that I "smelled like hot dogs" after each firing, an observation that reminds us that smell is both culturally packaged and closely linked to taste (Bradley 2015; Boulay 2018). But the smell of a firing is also linked to other cultural products and resources, specifically, firing fuel. The choice of kindling and wood for the fire must have had its own olfactory signature, with certain woods being more fragrant due to the presence of sap in them or even due to their origin (Draycott 2015). But the reduction phase required a somewhat different fuel, one that retains its heat even when choked of oxygen, thus maintaining the temperatures required for iron blacks to form. This is a difficult feat, as demonstrated in Figure 4, where choking the flame caused the temperature inside the kiln to plummet from 1000 to 800 degrees Celsius within a span of 25 minutes. Several types of reduction fuel, from charcoal to wet organic materials, have been proposed in the vase literature ${ }^{37}$, though none have been identified in kilns. One source of fuel found archaeologically in domestic and other non-kiln contexts is pomace, a cake-like form of the waste products of pressing olive oil which burns cleanly while also retaining heat (Rowan 2015). This finding offers the possibility that an image showing small round balls being raked out of a kiln by an attendant may be olive pits, not only charcoal as suggested in the literature. ${ }^{38}$ Pomace would have been easily available in Athens given the cultural and economic importance of its olive oil industry (Haland 2012) and the ability to use materials that would otherwise have been wasted would have perhaps

37 Cuomo di Caprio (1984) even mentions the use of cut up horses' hooves as a possibility for fuel.

38 See the Penteskouphia plaque currently in the collection of the Louvre, accession number MNB 2856. 
been a cost-savings for potters. In our own experimentation, we tested wet pine boughs, charcoal, cow manure, olive pits and olive pomace and found that each material had not only its own distinct ability (or inability) to hold heat but also produced its own distinctive smell. Notes from the firing logs attest to the difficulty of accurately describing smell, a familiar concern of the ancients (Bradley 2015) and include: "relatively pleasant smell of pine needles burning" (pine boughs); "burning smoke" (charcoal); "slow roasting shit" (cow manure); and "oily" (olive pits). The challenge of describing the smell without mentioning the substance from which it derives also recalls an ancient recognition of the elusive nature of smells and their links to other senses, including taste:

The Greeks, noting that the olfactory and gustatory modalities were physiologically associated, made use of the same semantics. Aristotle indicated that there is an analogy between the types of flavors and smells, but, "the odors not being quite as fully evident as the flavors, it is from the latter that the former derive their names. (Boulay 2018, p. 206)

It is tempting to consider whether potters chose their reduction fuel for their olfactory signatures as well as their performance, availability and cost. Did certain fuels signal cues in the reduction phase better than others? And if so, how did ancient kiln attendants smell? Was there an equivalent ancient odor to "hot dogs"?

\subsection{Sensory Phase 4: The Smell, Sound and Taste (?) of Red, Black and Purple Pots}

Knowing when to make the transition from the reduction phase to the re-oxidation phase requires the experience and skill of the kiln attendants as there are no absolute indicators that signal this change. Instead, the staff and perhaps the individual in charge of the firing, would have considered numerous factors: whether the reduction phase seemed to have gone on for long enough to ensure a "good black"; whether the smell of reduction was continuing and therefore worth extending; and whether test pieces drawn from the edge of the kiln shelves were a reasonable indicator of the entire kiln stack being suitably reduced. Based on these and likely other observations, the kiln might then be transitioned into the final "critical zone," one in which the oxygen ports were re-opened and burning and burned reduction fuel raked out of the firebox and replaced with new fuel (Figure 15). Perhaps this phase is depicted in an apprentice's plaque showing that black smoke continues to erupt from the chimney during the raking out of fuel, indicating that the kiln is still in reduction. ${ }^{39}$ A full transition to re-oxidation is indicated by a disappearance of the acrid smell of reduction and the sudden re-appearance and whooshing sound of an orange flame in the chimney. The key challenge during this firing phase is to maintain a temperature below the highest heat previously achieved inside the kiln as an overfiring could distort vessels and change "good" black surfaces to a dull gray-green. Here, too, the kiln attendants' experience in elevating the heat of the kiln without overheating it is crucial. In our experiments, carefully controlling the amount of fuel put into the firebox and listening for the excessive whooshing of the flame while checking our temperature gauges allowed us to limit overfiring. As previously mentioned, the re-introduction of oxygen changes the unslipped surfaces from black to red. However, slipped areas remain black as oxygen cannot diffuse through the thin layer of glass that has formed on those surfaces. Additionally, painted inscriptions made with a mixture of slip and iron-oxide pigments form a combination of the black and red iron oxides, often appearing purple or purplish-red. After a short period of maintaining these elevated temperatures-less than an hour in our firings-the firebox of the kiln is bricked up and the temperature is allowed to fall. The chimney, however, is left open, allowing air to enter the kiln to vent and cool it gradually.

39 See Penteskouphia Pinax, MNB 2856, Louvre, dated 575-550 BCE. 

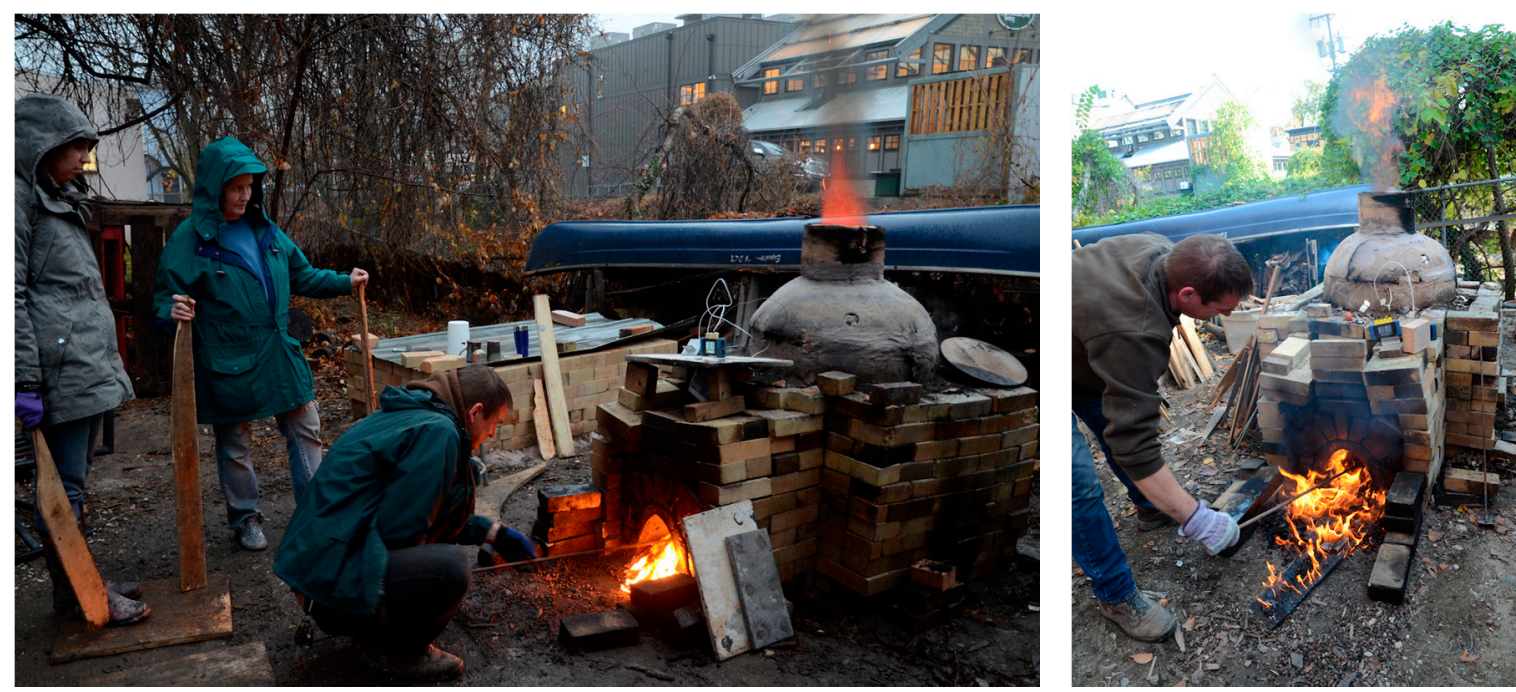

Figure 15. Raking out the reduction fuel in order to begin re-oxidation.

An aspect of the firing that much of the art historical and the scientific literature neglects is the anxiety that pervades its end. Both ancient and contemporary potters, as well as ancient philosophers, would likely agree that the lack of control over what happens inside a kiln is a powerful reminder of the limitations of what we can know with our senses. Even if all sensory indicators and even test pieces suggested that the firing had gone well, the final result of the firing is not certain until the kiln cools and is opened. After all, "only when [the vessel] has left the kiln does it become pottery, solid and with sufficient strength to defy the centuries" (Cuomo di Caprio 1984, p. 72). Given the different micro-environments that exist even from one part of the kiln to the next, some pots may have been perfectly fired while others were misshapen or a gray-green from overfiring or a dull red from underfiring or only partially reduced to black with the "ghosts" of vessels stacked next to them visible on their surfaces (Noble [1965] 1988, pp. 162-64). We have no ancient images of the opening of kilns and none of the end of the long firings to show us ancient makers' bodies in repose. Instead, we can only imagine them-worn, dirty, with the reek of smoke clinging to their nostrils, hair and clothes as they left the Kerameikos for home. Perhaps some ate a hasty meal and remained on site overnight to watch the kiln. No doubt some fretted over whether the firing had been successful, if that ping or pop in an earlier phase had signaled disaster or if the acrid smoke of reduction had lasted long enough to turn the pots fully black. Thus, the end of the firing might be more associated with the churning and evaluative thoughts about the firing in the minds of ancient makers now that their bodies were finally at rest. Greek philosophers do not address this intellectual activity that was certainly part of the work of ceramics production: the calculations of potential gain or loss, the evaluations of what might need to be changed for the next firing or even an appraisal of how different members of the workgroup fared. To ignore this mental work of the firing is to forget that the production of vases was a livelihood for these ancient people and one that depended on both an attuned body as well as an attuned mind.

\section{Conclusions}

A young man shopping for his first set of ceramics in a potter's shop ${ }^{40}$ (Figure 16) might have been entirely unaware of the sensory signatures indicated by the shining black and deep red surfaces of the pots he was considering for purchase. But the shop proprietor, perhaps even the potter himself/herself/themselves might have struck a cup with a fingernail, bringing "forth a sharp clear

40 See Langdridge-Noti (2015) on buying pots. 
sound" ${ }^{\prime 1}$ to indicate its solidity. The sheen of the black slip might have been scrutinized in bright sunlight to show its depth or the cup itself filled with a liquid to prove its water-tightness or emphasize how beads of moisture would cling to its external surface, deepening the black color (Figure 17). Perhaps liquid was sloshed in a painted vessel, allowing the glistening images to appear and disappear (Watch Supplementary Multimedia File 4). Might certain dining or cooking pots have been extolled for the iron-rich taste they did (or did not) impart to foods (Wolfert 2009)? In fact, did food and drink stored or served in Athenian ceramics have a distinctive taste reminding consumers of that vessel as a "product of a region, a certain type of soil, a microclimate, of [the] availability of water" 42 ? To thus re-animate these ceramics as functional vessels meant to be held and used as containers reminds us of the intentionality of all of their surfaces, not only their painted images. Imagining potters showing off their wares synaesthetically to potential customers offers the possibility that, for these ancient makers, the sensory production of color continued post-firing; that is, they were aware that their ceramics took on other shades as they were viewed in different lights, filled with various substances and held in others' hands. The constantly changing nature of the color of these surfaces also offers insight into why ancient authors do not mention color in relation to vessels but rather describe their sheen or luminosity. While this has led some scholars to suggest that ancient writers are describing metal containers (Vickers 1985; Vickers and Gill 1994), I would argue that the changeability of "red" and "black" ceramics-based on lighting and use-made them difficult to categorize; sheen, however, is often a constant, whether speaking of a glassy black surface or one slick with droplets.

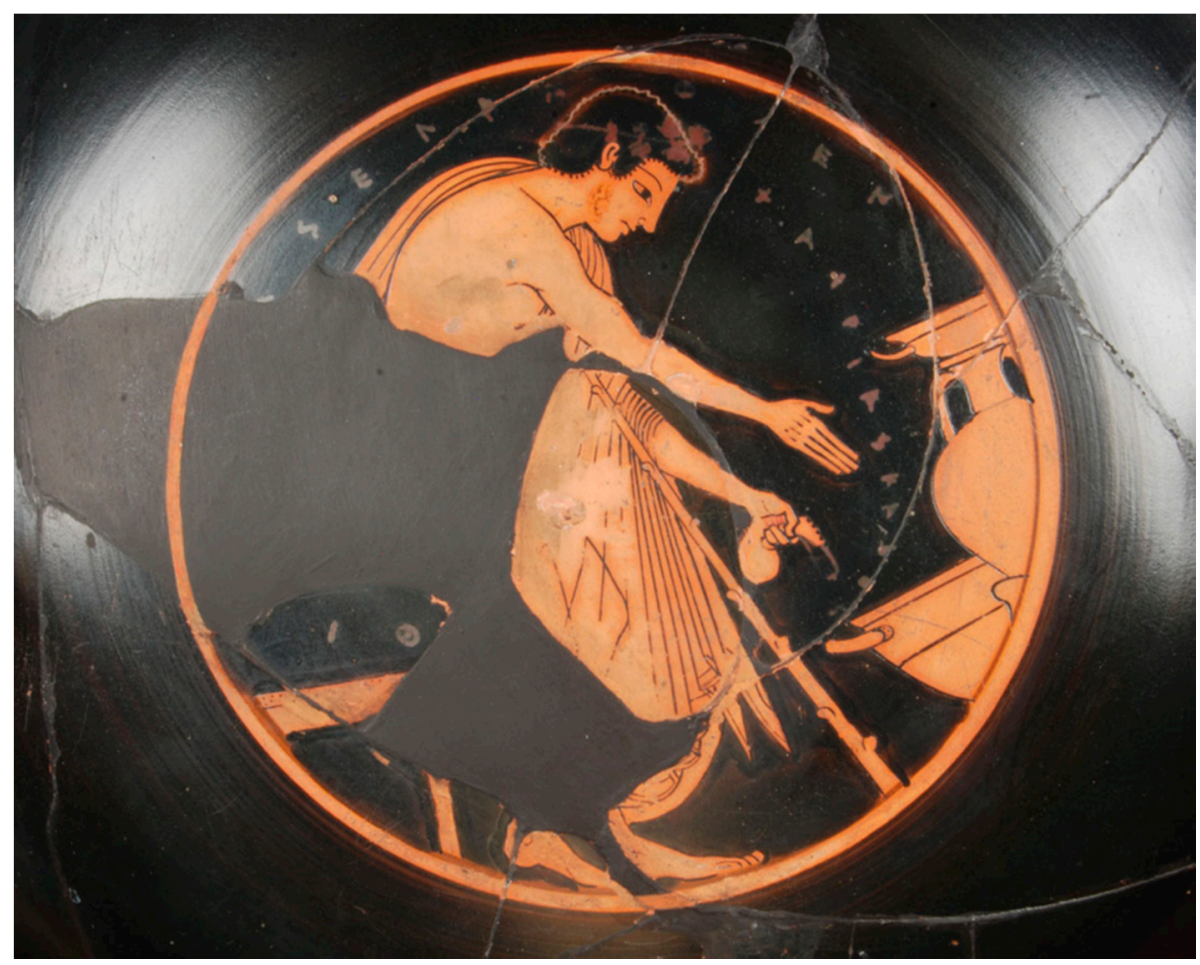

Figure 16. Detail of a red figure cup signed by Phintias as painter, ceramic, Greek, 510 BCE, Image courtesy of the Johns Hopkins Archaeological Museum.

41 As mentioned in Geoponia VI, 3, as a way to test the quality of a pithos. See Richter (1923, p. 88).

42 Boulay (2018, p. 210). Though Boulay is speaking of wine in this instance, the same characteristics apply to ceramics production. 

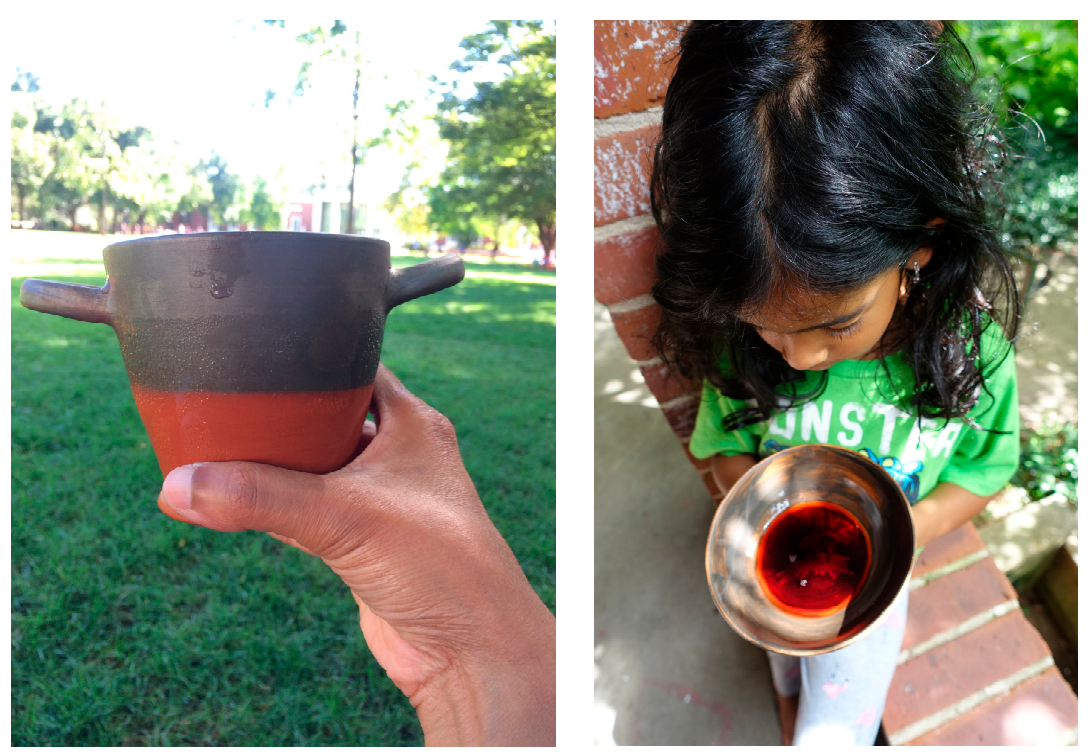

Figure 17. (Left) "Sweating" skyphos filled with water. (Right) Changes in the color of the vessel in sunlight and when filled with cherry juice.

To see and hold the "red" and "black" ceramics of ancient Greece is to see and recognize the bodies, the sensory experience, the physical labor and the extraordinary expertise of the people who fired them. An awareness of the sensory experiences of the ancient potters and painters as they made these objects also forces us to acknowledge the difficult, full-bodied physical and intellectual labor of the non-elite, mostly metic workers that made the pleasure of elite Athenians possible. These low status people were of course barred from events such as the symposium, with Plato musing ${ }^{43}$ :

We could make the potters recline on couches from left to right before the fire drinking toasts and feasting with wheel alongside to potter with when they are so disposed ... But urge us not to do this, since, if we yield [the potter] will not be ... a potter.

Despite this deliberate exclusion, the potters' objects, full of their makers' embodied experiences, were present in these rarified spaces and essential to the sensory and intimate worlds of the purchasers of their wares. While the more traditional kinds of evidence-archaeological, literary and epigraphic-might not record the physical bodies of these artisans, the objects they made and the sensory experiences accessible in the surfaces of those objects offer other ways to know these ancient people. I would argue that we have not tried to know them on their own terms. The objects they made tell us about who they were in their own specialized visual—and sensory-language. We only need to be willing to look, touch, listen, smell and even taste.

Supplementary Materials: The following are available online at http://www.mdpi.com/2076-0752/8/2/70/s1, Multimedia Files 1-4.

Acknowledgments: I am grateful to the Johns Hopkins University Program in Museums and Society (particularly Elizabeth Rodini), The Andrew W. Mellon Foundation, The Johns Hopkins University Discovery Grant, and the Getty Conservation Institute for the support to pursue these test firings and subsequent studies. I am especially grateful to Matthew Hyleck, master potter, whose extraordinary skill and patience made this project possible. Thanks to my other fellow makers Camila Ascher, Ross Brendle, Patricia McGuiggan, Karun Pandian and Anastassia Sovolieva. Thank you to all thirteen Johns Hopkins University students in the 2015 course, "Recreating Ancient Greek Ceramics." This project is also indebted to the generosity of David Saunders and Karen Trentelman. I am grateful to Annette Giesecke for her translation of the poem "Kiln" poem, and I thank her and Mark Stansbury-O'Donnell for their thoughtful and generous comments on drafts of this paper. I would also like to thank the anonymous reviewers for their suggestions on an earlier version of this paper.

43 From Plato's Republic 420e-421a, as translated by Shorey. See Hedreen (2016, p. 4). 
Conflicts of Interest: The author declares no conflict of interest.

\section{References}

Aloupi-Siotis, Eleni. 2008. Recovery and Revival of Attic-Vase Decoration Techniques: What Can They Offer Archaeological Research? In Papers on Special Techniques in Athenian Vases. Edited by Kenneth Lapatin. Los Angeles: The J. Paul Getty Museum, pp. 113-28.

Balachandran, Sanchita. 2018. Uncovering Ancient Preparatory Drawings on Greek Ceramics. The Iris. Available online: http://blogs.getty.edu/iris/uncovering-ancient-preparatory-drawings-on-greek-ceramics/ (accessed on 4 December 2018).

Arrington, Nathan T. 2017. Connoisseurship, Vases and Greek Art and Archaeology. In The Berlin Painter and His World: Athenian Vase-Painting in the Early Fifth Century B.C.. Edited by J. Michael Padgett. Princeton: Princeton University Art Museum, pp. 21-39.

Boulay, Thibaut. 2018. Tastes of Wine: Sensorial Wine Analysis in Ancient Greece. In Taste and the Ancient Senses. Edited by Kelli C. Rudolph. Abingdon: Routledge, pp. 197-211.

Bradley, Mark. 2013. Color As Synaesthetic Experience in Antiquity. In Synaesthesia and the Ancient Senses. Edited by Shane Butler and Alex Purves. Durham: Acumen Publishing, pp. 127-40.

Bradley, Mark, ed. 2015. Smell and the Ancient Senses. London: Routledge.

Butler, Shane, and Sarah Nooter, eds. 2018. Sound and the Ancient Senses. Abingdon: Routledge.

Butler, Shane, and Alex Purves, eds. 2013. Synaesthesia and the Ancient Senses. Durham: Acumen Publishing.

Chatzedemetriou, Athena N. 2005. Parastaseis Ergastēriōn kai Emporiou Stēn Eikonographia Tōn Archaïkōn Kai Klasikōon Chronōn. Athēna: Tameio Archaiologikōn Porōn Kai Apallotriōseōn.

Chaviara, Artemi, and Eleni Aloupi-Siotis. 2016. The Story of a Soil That Became a Glaze: Chemical and Microscopic Fingerprints on the Attic Vases. Journal of Archaeological Science: Reports 7: 510-18. [CrossRef]

Cianchetta, Ilaria, Karen Trentelman, Jeffrey Maish, David Saunders, Brendan Foran, Marc Walton, Philippe Sciau, Tian Wang, Emeline Pouyet, Marine Cotte, and et al. 2015a. Evidence for an Unorthodox Firing Sequence Employed by the Berlin Painter: Deciphering Ancient Ceramic Firing Conditions through High-Resolution Material Characterization and Replication. Journal of Analytical Atomic Spectroscopy 30: 666-76. [CrossRef]

Cianchetta, Ilaria, Jeffrey Maish, David Saunders, Marc Walton, Apurva Mehta, Brendan Foran, and Karen Trentelman. 2015b. Investigating the Firing Protocol of Athenian Pottery Production: A Raman Study of Replicate and Ancient Sherds. Journal of Raman Microscopy 46: 996-1002. [CrossRef]

Cohen, Beth, ed. 2006. Colors of Clay. Special Techniques in Athenian Vases. Los Angeles: J. Paul Getty Museum.

Cuomo di Caprio, Ninina. 1984. Pottery Kilns on Pinakes from Corinth. In Ancient Greek and Related Pottery: Proceedings of the International Vase Symposium in Amsterdam 12-15 April, 1984. Edited by Herman A. G. Brijder. Amsterdam: Allard Pierson Series, pp. 72-82.

Day, Jo. 2013. Making Senses of the Past. Toward a Sensory Archaeology. Carbonadale: Southern Illinois University Press.

Dembin, Einav Z. 2018. Voicing the Past: The Implications of Craft-referential Pottery in Ancient Greece. In The Adventure of the Illustrious Scholar: Papers Presented to Oscar White Muscarella. Edited by Elizabeth Simpson. Boston: Brill, pp. 537-63.

Draycott, Jane. 2015. Smelling Trees, Flowers and Herbs in the Ancient World. In Smell and the Ancient Senses. Edited by Mark Bradley. London: Routledge, pp. 60-73.

Gliozzo, Elisabetta, Ian W. Kirkman, E. Pantos, and Isabella Memmi Turbanti. 2004. Black Gloss Pottery: Production Sites and Technology in Northern Etruria. Part II, Gloss Technology. Archaeometry 46: 227-46. [CrossRef]

Haland, Evy J. 2012. The Ritual Year of Athena: The Agricultural Cycle of the Olive, Girls' Rites of Passage and Official Ideology. Journal of Religious History 36: 256-84. [CrossRef]

Hamilakis, Yannis. 2013. Archaeology and the Senses. Cambridge: Cambridge University Press.

Hasaki, Eleni. 2002. Ceramic Kilns in Ancient Greece: Technology and Organization of Ceramic Workshops. Ph.D. dissertation, University of Cincinnati, Cincinnati, OH, USA.

Hasaki, Eleni. 2012. Craft Apprenticeship in Ancient Greece. In Archaeology and Apprenticeship: Body knowledge, Identity and Communities of Practice. Edited by Willeke Wendrich. Tucson: University of Arizona Press, pp. 171-202. 
Hedreen, Guy M. 2016. The Image of the Artist in Archaic and Classical Greece: Art, Poetry and Subjectivity. New York: Cambridge University Press.

Heilmeyer, Wolf-Dieter. 2004. Ancient Workshops and Ancient 'Art'. Oxford Journal of Archaeology 23: 403-15. [CrossRef]

Hitch, Sarah. 2018. Tastes of Greek Poetry: From Homer to Aristotle. In Taste and the Ancient Senses. Edited by Kelli C. Rudolph. Abingdon: Routledge, pp. 45-59.

Hurwit, Jeffrey M. 2015. Artists and Signatures in Ancient Greece. New York: Cambridge University Press.

Hyleck, Matthew, Lisa C. Kahn, John Wissinger, and Sanchita Balachandran. 2016. Recreating Greek Pottery. Recreating a Working Greek Kiln. National Council on Education for the Ceramic Arts Journal 37: 90-91.

Kamen, Deborah. 2013. Status in Classical Athens. Princeton: Princeton University Press.

Kasimis, Demetra. 2018. The Perpetual Migrant and the Limits of Athenian Democracy. Cambridge: Cambridge University Press.

Kennedy, Rebecca. F. 2014. Immigrant Women in Athens: Gender, Ethnicity and Citizenship in the Classical City. New York: Routledge, Taylor \& Francis Group.

Kingery, W. David. 1991. Attic Pottery Gloss Technology. Archaeomaterials 5: 47-54.

Langdridge-Noti, Elizabeth M. 2015. 'To Market, To Market': Pottery, The Individual and Trade in Athens. In Cities Called Athens. Studies Honoring John M. Camp II. Edited by Kevin F. Daly and Lee Ann Riccardi. Lanham: Bucknell University Press, pp. 165-95.

Lapatin, K., ed. 2008. Papers on Special Techniques in Athenian Vases. Los Angeles: J. Paul Getty Museum.

Lewis, Sian. 2010. Images of Craft on Athenian Pottery: Context and Interpretation. Bollettino di Archeologia On Line 1: $12-26$.

Lühl, Lars, Bernhard Hesse, Ioanna Mantouvalou, Max Wilke, Sammia Mahlkow, Eleni Aloupi-Siotis, and Birgit Kanngiesser. 2014. Confocal XANES and the Attic Black Glaze: The Three-Stage Firing Process Through Modern Reproduction. Analytical Chemistry 86: 6924-30. [CrossRef] [PubMed]

Maish, Jeffrey P. 2008. Observations and Theories on the Technical Development of Coral-Red Gloss. In Papers on Special Techniques in Athenian Vases. Edited by Kenneth Lapatin. Los Angeles: The J. Paul Getty Museum, pp. 85-94.

Maniatis, Yannis, Eleni Aloupi, and A. D. Stalios. 1993. New Evidence for the Nature of the Attic Black Gloss. Archaeometry 35: 23-34. [CrossRef]

Noble, Joseph V. 1988. The Techniques of Painted Attic Pottery. Revised Edition. London: Thames and Hudson. First published 1965.

Papadopoulos, John K. 2003. Ceramicus Redivivus. The Early Iron Age Potters' Field in the Area of the Classical Athenian Agora. Hesperia Supplements. Princeton: American School of Classical Studies in Athens, vol. 31.

Purves, Alex, ed. 2018. Touch and the Ancient Senses. Abingdon: Routledge.

Richter, Gisela M. A. 1923. The Craft of Athenian Pottery: An Investigation of the Technique of Black-Figured and Re-Figured Athenian Vases. New Haven: Yale University Press.

Rowan, Erica. 2015. Olive Oil Pressing Waste as a Fuel Source in Antiquity. American Journal of Archaeology 119: 465-82. [CrossRef]

Rudolph, Kelli C., ed. 2018. Taste and the Ancient Senses. Abingdon: Routledge.

Sanidas, Giorgos M. 2013. La Production Artisanale en Grece. Lille: Editions du Comite des Travaux Historiques et Scientifiques.

Sapirstein, Philip. 2013. Painters, Potters and the Scale of the Attic Vase-Painting Industry. American Journal of Archaeology 117: 493-510. [CrossRef]

Saunders, David A., Karen Trentelman, and Jeffrey Maish. forthcoming. Collaborative Investigations into the Production of Athenian Painted Pottery. In New Approaches to Ancient Material Culture. Edited by Kate Cooper and Alison Surtees.

Schreiber, Toby. 1999. Athenian Vase Construction. A Potter's Analysis. Los Angeles: J. Paul Getty Museum. Squire, Michael, ed. 2016. Sight and the Ancient Senses. London: Routledge.

Stissi, Vladimir. 2012. Giving the Kerameikos a Context: Ancient Greek Potters' Quarters as Part of the Polis space, Economy and Society. In "Quartiers" Artisanaux en Grèce Ancienne: Une Perspective Méditerranéenne. Edited by Arianna Esposito and Giorgos M. Sanidas. Villeneuve d'Ascq: Presses Universitaires du Septentrion, pp. 201-30. 
Stissi, Vladimir. 2016. Minor Artisans, Major Impact? In Töpfer Maler Werkstatt. Edited by Norbert Eschbach and Stefan Schmidt. Munich: C. H. Beck, pp. 47-53.

Tonks, Oliver S. 1908. Experiments with the black glaze on Greek vases. American Journal of Archaeology 12: 417-27. [CrossRef]

Venit, Marjorie S. 1988. The Caputi Hydria and Working Women in Classical Athens. The Classical World 81: 265-72. [CrossRef]

Vickers, Michael J. 1985. Artful Crafts: The Influence of Metal Work on Athenian Painted Pottery. The Journal of Hellenic Studies 105: 108-28. [CrossRef]

Vickers, Michael J., and David W. J. Gill. 1994. Artful Crafts: Ancient Greek Silverware and Pottery. Oxford: Oxford University Press.

Walton, Marc, Karen Trentelman, Marvin Cummins, Giulia Poretti, Jeffrey Maish, David Saunders, Brendan Foran, Miles Brodie, and Apurva Mehta. 2013a. Material Evidence for Multiple Firings of Ancient Athenian Red-Figure Pottery. Journal of the American Ceramic Society 96: 2031-35. [CrossRef]

Walton, Mark, Karen Trentelman, Jeffrey Maish, David Saunders, Brendan Foran, Piero Pianetta, and Apurva Mehta. 2013b. Compositional Characteristics of Athenian Black Gloss Slips (5th c. B.C.). Microscopy and Microanalysis 19: 1400-1. [CrossRef]

Walton, Marc, Karen Trentelman, Ilaria Cianchetta, Jeffrey Maish, David Saunders, Brendan Foran, and Apurva Mehta. 2015. Zn in Athenian Black Gloss Ceramic Slips: A Trace Element Marker for Fabrication Technology. Journal of the American Ceramic Society 98: 430-36. [CrossRef]

West, Martin L. 2003. Homeric Hymns, Homeric Aprocrypha, Lives of Homer. Cambridge: Harvard University Press, pp. 391-95.

Williams, Dyfri. 2009. Picturing Potters and Painters. In Athenian Potters and Painters Volume II. Edited by John H. Oakley and Olga Palagia. Oxford: Oxbow Books, pp. 306-17.

Williams, Dyfri. 2016. Peopling Athenian Kerameia: Beyond the Master Craftsmen. In Töpfer Maler Werkstatt. Edited by Norbert Eschbach and Stefan Schmidt. Munich: C. H. Beck, pp. 54-68.

Williams, Dyfri. 2017. Beyond the Berlin Painter: Toward a Workshop View. In The Berlin Painter and His World: Athenian Vase-Painting in the Early Fifth Century B.C.. Edited by J. Michael Padgett. Princeton: Princeton University Art Museum, pp. 144-88.

Wissinger, John C., and Lisa C. Kahn. 2008. Re-creating and Firing a Greek Kiln. In Papers on Special Techniques in Athenian Vases. Edited by Kenneth Lapatin. Los Angeles: The J. Paul Getty Museum, pp. 129-38.

Wolfert, Paula. 2009. Mediterranean Clay Pot Cooking. Hoboken: John Wiley and Sons, Inc. 